SWPRINA 2 HENGISTSURY HEAD

Reports of the Research Committee of the

Society of Antiquaries of London

No. V

Excavation of the Late-Celtic

Urn-field at Swarling

Kent

By J. P. Bushe-Fox, F.S.A.

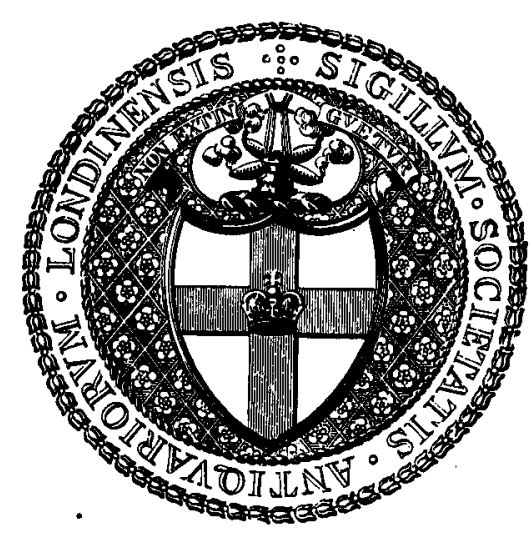

Oxford

Printed by Frederick Hall for The Society of Antiquaries Burlington House, London 1925 


\section{SOCIETY OF ANTIQUARIES}

\section{RESEARCH COMMITTEE}

The Earl of Crawford and Balcarres, K.T., LL.D., F.R.S., President.

Sir C. Hercules Read, LL.D., Hon. Vice-President.

Sir Arthur J. Evans, M.A., D.Litt., F.R.S., Hon. Vice-President.

W. Minet, M.A., Treasurer.

Charles R. Peers, C.B.E., M.A., Director.

Ralph Griffin, Secretary.

J. N. BANKES.

Harold Brakspear.

J. P. Bushe-Fox.

Rev. G. H. Engleheart, M.A.

Lt.-Col. William Hawley.

E. Thurlow Leeds, M.A.

D. H. Montgomerie.

William Page.

Reginald A. Smith, B.A.

Mill Stephenson, B.A.

W. M. TAPP, LL.D.

H. S. KIngSFord, M.A., Assistant-Secretary. 


\section{CONTENTS}

General Summary $\quad \cdot \quad \cdot \quad \cdot \quad \cdot \quad \cdot \quad \cdot \quad \cdot$.

Description of the Graves . . . . . . . . . . 4

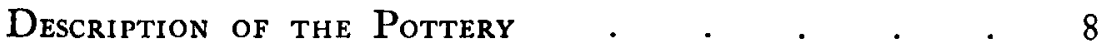

Continental Prototypes and Parallels . . . I 5

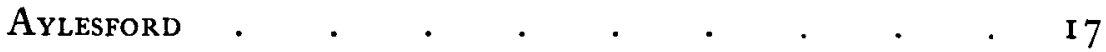

DeAL . . . . . . . . . . . $\quad$. 18

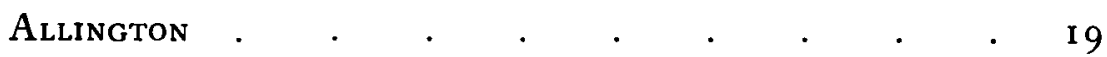

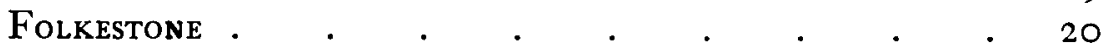

Colchester and other Places in Essex . . . . 2 I

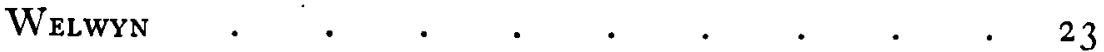

Hauxton, Duston, Weekley. . . . . . . 24

Dating of Swarling Pottery . . . . . . 24

Summary of Dating Evidence . . . . . $\quad . \quad 27$

The Distribution of the Aylesford-Swarling Type in

Britain . . . . . . . . . 27

Historical Conclusions . . . . . . . . 30

\section{APPENDICES}

I. The Brooches, by Reginald A. SMith, F.S.A. . - 40

II. A. Revolts, \&c. in Gaul after the withdrawal of Caesar, by Donald Atrinson, M.A. . . . . 46

B. Invasions of Cimbri and Teutones, by Donald Atrinson, M.A. . $\quad$. $\quad . \quad$. $\quad$. $\quad$. 47

III. The Iron-smelting Works, by C. LEenard Woolley, M.A. • . . . $\cdot$.

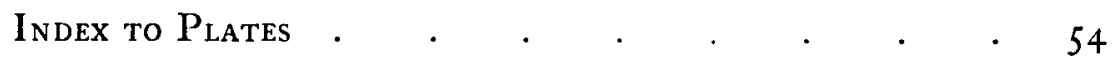




\title{
Excavation of the Late-Celtic Urn-field at Swarling, Kent
}

\author{
By J. P. Bushe-Fox, F.S.A.
}

$T_{H E}$ finding of the urn-field at Swarling and the recognition of its importance must be placed to the credit of $\mathrm{Mr}$. Reginald Smith, F.S.A., and Dr. Ince, of Sturry, who, when visiting the gravel-pits in search of palaeoliths, learnt that the gravel-diggers, during the course of their work, had come across a considerable number of pottery vessels and a few bronze objects. The greater part of these finds had, however, been destroyed, but sufficient were secured to give a clue to the date of the cemetery. On the matter being reported to the Research Committee of the Society of Antiquaries, that body decided to carry out the excavation of the site. Most fortunately the owner of the land, Mr. Arthur $D$. Collard, was quick to recognize the archaeological value of the undertaking, and gave not only free permission to dig, but every facility for expediting the work.

The Swarling gravel-pits are on the south side of the valley and about 500 yards to the south-west of Swarling Manor (fig. I). They are cut into a brow of the hill roughly at the $200 \mathrm{ft}$. contour line of the Ordnance Survey. Above this the ground is almost level, sloping up very gently to the south; below, it falls in a smooth but fairly steep slope to the valley bottom. Gravel-digging had been started along a line a little below and approximately parallel to this brow, and had driven irregularly into the hill-side, leaving isolated two islands of untouched ground. The labourers who had worked on the gravel were positive that below the brow no vases, at least nothing more than fragments of pottery, had come to light, and that only when they came to the plateau edge did they hit upon considerable remains and complete grave-groups.

In the summer of I92I, Mr. C. L. Woolley, on behalf of the Society of Antiquaries, carried on the excavation of the urn-field for a fortnight. Throughout the whole of this time he was assisted by Mr. C. G. H. Dicker, and during the first week by Mr. G. H. Locket, both undergraduates of Oxford University, introduced by the Ashmolean Museum. An area of some $60 \mathrm{ft}$. by $30 \mathrm{ft}$. on the edge of the south side of the quarry was surface- 
cleared, resulting in the discovery of 13 graves (pl. XVI). $\mathrm{Mr}$. Woolley was influenced in his choice of this particular area by the fact that burials had been found in the vicinity by the gravel-diggers. The two islands of gravel which had been left isolated in the quarry were also tested by him. No burials were found, but the remains of what appeared to be an iron-smelting furnace were brought to light. Mr. Woolley made a preliminary report to the Research Committee: this has not been printed separately, but incorporated in the present Report, with the exception of his description of the furnace, which is added as an Appendix.

The work was resumed in the autumn under the direction of the writer, assisted by Mr. Thomas May, F.S.A., the latter undertaking the drawing and description of the pottery. The excavations continued for four weeks, but although the whole of the ground adjoining the area examined by $\mathrm{Mr}$. Woolley, as well as the smaller island and the greater part of the larger one, were cleared and several new places tested, only five more graves were discovered, and it would appear that the western and south-western limits of the cemetery have been reached. This seems to be extremely likely, as the gravel-diggers reported that urns had been found in the wood to the east of the site, making the area over which the cemetery extended at least some $500 \mathrm{ft}$. in length (fig. I). Excavation in this wood is practically impossible owing to the number of large trees and their spreading roots. There is no record of burials having been met with in the wood to the south of the gravel-pit, and as the open area immediately to the south and south-west of the spot where the graves were found has been thoroughly tested without result, it would seem that no further work can be undertaken with satisfactory results.

The site had been under cultivation before being used as a gravel-pit, and in consequence the soil was much disturbed by the plough and the planting of hops. As a result many of the urns which had been deposited in the top soil were broken, parts of some having entirely disappeared. A few of the grave-pits, however, had been dug into the gravel and the urns in these were better preserved, although the majority were broken, either through being struck by the large flints when the graves were originally filled in, or by the pressure of the soil. In a few instances the pots were so crushed and distorted that it proved very difficult to restore their original form with any certainty. The locating of the burials in the natural gravel was far from easy, as, quite apart from the fact that its consistency was nearly that of concrete, and picks were often broken in consequence, the grave-pits had in many. cases been refilled with gravel, and there was therefore 
no indication of a burial until part of a vessel or fragments of bone came to light.

The bottom of the deepest grave-pit was a little over $3 \mathrm{ft}$. from the surface, and in order to ensure as far as possible that no burials should be missed, the whole of the soil in the area opened out was examined to a depth of about $4 \mathrm{ft}$.

In one case the grave-pit (no. 4) had been lined with a regular

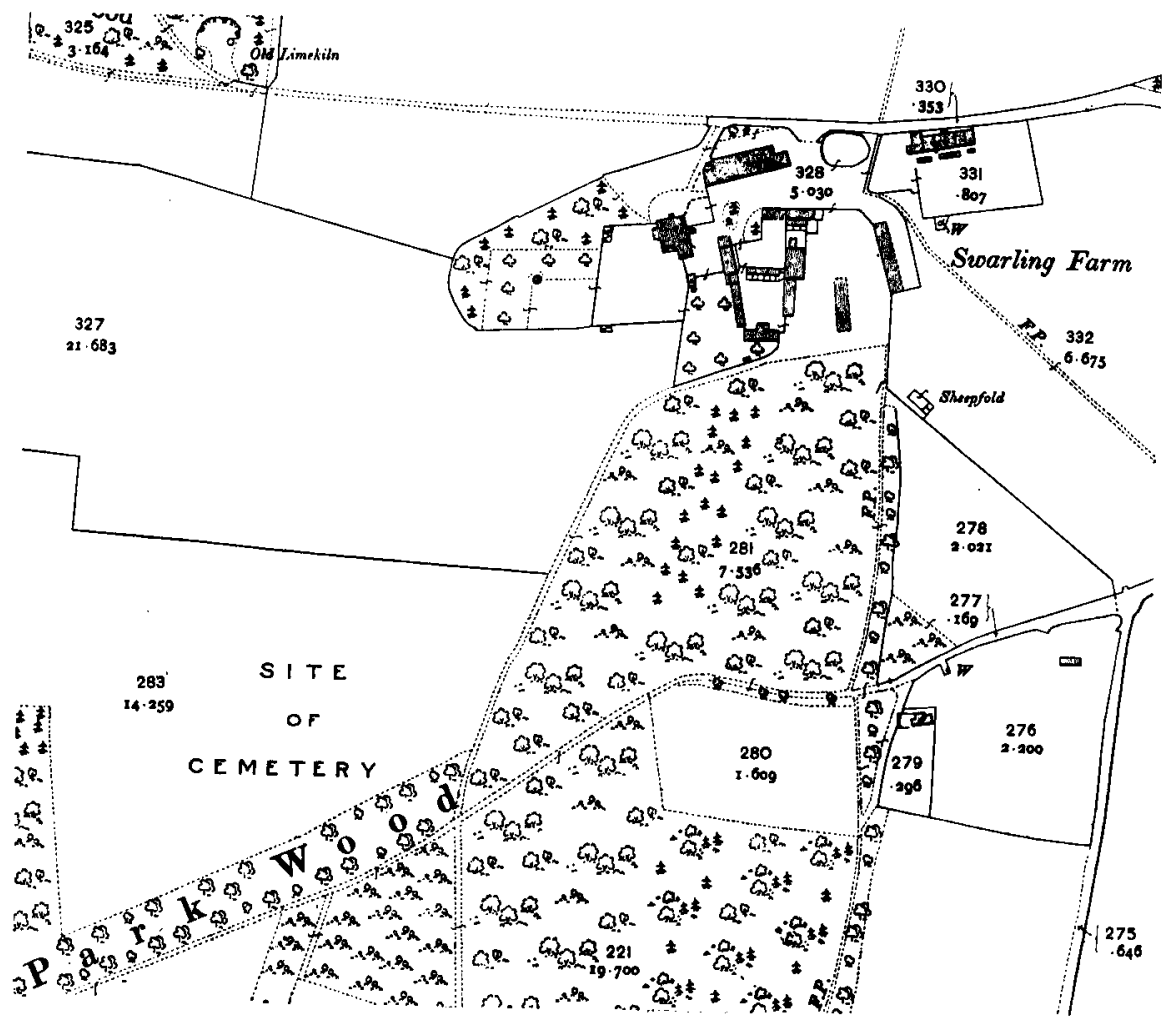

FIG. 1. Plan showing site of the cemetery at Swarling.

(Keduced from the Ordnance Sunder Map by permission of the Conlroller of II.M. Stationery Office.)

ring of good-sized flints, and in several, large flints were carefully placed against the sides of an urn to keep it in position. This was particularly noticeable in the case of no. 13 , where the filling of the grave-pit was of tine light soil, free of stones, a few large flints being wedged firmly against the pedestals of the vases. In one instance (no. 5) the cinerary urn was inverted and lay quite level, with its mouth resting on two or three large flat flints, obviously placed there for the purpose. 


\section{REPORTS OF THE SOCIETY OF ANTIQUARIES}

The irregular spacing of the graves and the fact that in no instance was one superimposed on or cut into another suggest that their position was originally marked in some way, such as by a wooden stake, a slight mound, or a heap of stones.

The graves fall roughly into two groups, the eastern consisting of nine and the western of ten (pl. XVI). It is not, however, certain that the grouping has any significance, or that either group is complete, as, both being just on the edge of the gravel-pit, other burials in the vicinity may have been destroyed before the excavations were begun. The gravel-diggers, however, stated that when a burial was found there were generally others in the immediate neighbourhood, and it therefore appears likely that they were in groups as was noticed at Aylesford and elsewhere.

With the exception of the contents of the graves and the discovery of the remains of iron-smelting works (Appendix III), nothing of any importance was met with during the excavation. Fragments of late Celtic pottery, probably from burial urns broken by the plough, were occasionally found in the soil, as were also a few pieces of Roman and medieval vessels, \&c.

\section{DESCRIPTION OF THE GRAVES.}

I. Found by the gravel-diggers before the excavations were undertaken, approximately at the spot marked on the plan. It contained an urn (pl. VIII, no. I $_{5}$ ) in which was a fibula (pl. XII, no. 4).

2. Diameter $2 \mathrm{I}$ in., sunk $\mathrm{I} 2 \mathrm{in}$. in the gravel, bottom of grave 27 in. below present surface. Part of the burial had been cut away by the gravel-diggers, and fragments of the urns were exposed in the quarry face. These were :

(A) Pedestal urn (pl. VI, no. 2), empty.

(B) " " (pl. VII, no. 5), containing calcined bones and ashes. In" the earth removed by the gravel-diggers at the time when these urns were found were three small fragments of iron, two flat and thin, the third a slender rod or wire; they probably came from this grave.

3. The grave-pit had been dug down to the top of the gravel, which at this point was 15 in. below the present surface. It contained a beaker (pl. VIII, no. ${ }_{3} 3$ ) holding a few highly calcined bones, apparently those of a young child, and some wood ash. The beaker was standing upright on the gravel, the rim apparently having been cut away by the plough. 
4. The bottom of the grave-pit was on the gravel 15 in. below the present surface, and had been lined with a regular ring of goodsized flints. It contained :

(A) The base and a few other fragments of a pedestal urn (pl. VII, no. 7).

(B) An urn (pl. IX, no. 3 I) containing broken bones, apparently those of a child, showing little or no signs of burning, also

(c) A broken iron fibula (pl. XII, no. I).

There was a definite ring-packing of flints round the pots, between which and the walls of the grave was loose soil containing only small stones.

5. The grave was only slightly dug into the gravel, the bottom being 22 in. below the present surface : the sides were irregular, but it seems to have measured about 24 in. by Io in. It contained :

(A) A beaker (pl. IX, no. 34), empty.

(B) Cup or beaker (pl. IX, no. 27), empty.

(c) A bowl (pl. IX, no. 28), containing a quantity of bones and ash.

A and $\mathbf{B}$ stood close together; $\mathrm{c}$ was mouth downwards, and lay quite level, with its mouth resting on two or three large flat stones obviously placed there for the purpose (pl. I, fig. I).

6. Depth of pit $20 \mathrm{in}$. below present surface. It contained a tall conical urn (pl. VII, no. ro) in which were calcined bones and ashes.

7. Depth of pit I 9 in. below present surface. It contained a pedestal urn (pl. VII, no. 6) in which were a few fragments of calcined bones.

8. Bottom of pit $\mathbf{I} 2$ in. in the gravel. It contained :

(A) A beaker ( $p l$. VIII, no. I 8), empty.

(B) " (pl. VIII, no. I 4), containing calcined bones.

(c) A cúp (pl. IX, no. 30), empty.

The three vessels were standing touching each other (see pl. I, fig. 2).

9. Grave about $24 \mathrm{in}$. in diameter and sunk $12 \mathrm{in.}$ in the gravel. It contained :

(A) An urn (pl. VIII, no. I 7). bone.

(B) An urn (pl. VIII, no. 2 I), containing a few pieces of calcined

(c) A bowl (pl. IX, no. 29).

$A$ and $\mathrm{B}$ were close together; $c$ lay on its side at a little distance away (pl. II, fig. I). 


\section{REPORTS OF THE SOCIETY OF ANTIQUARIES}

10. Depth of pit 12 in. below present surface. It contained fragments only of a flat-bottomed jar of brownish-black clay, coarse and roughly worked (not illustrated). The vessel was lying on its side and was empty. It is possible this was not a burial.

I I. Depth of pit 17 in. below present surface. It contained an urn (pl. IX, no. 32) which was crushed in and empty. Possibly not a burial.

I2. Depth of pit 12 in. below present surface. It contained only a few fragments of a vessel of reddish-brown clay, flat based, with lightly impressed cordons (not illustrated). Some pieces of lightly calcined bone were found with it.

I 3. Grave roughly circular, $3 \mathrm{ft}$. 6 in. in diameter, cut into the gravel, and a little over $3 \mathrm{ft}$. deep. It contained :

(A) A pedestal urn (pl. VI, no. 4), empty.

(B) ", "(pl. VI, no. 3), ,

(c) A bowl (pl. IX, no. 25), empty.

(D) " (pl. IX, no. 22), "

(E) " (pl. IX, no. 26), ",

(F) " (pl. IX, no. 23), ,

(G) The remains of a wooden bucket with iron hoops and handles.

(H) A bronze fibula (pl. XII, no. 3).

(I) A bronze fibula of similar type.

(K) Two round pebbles, one of which may have served as a loom-weight (in a hole in the top of the stone there were traces of iron rust as if a hook or ring had been inserted).

Large flints had been wedged against the pedestals of $A$ and $B$ to keep them upright, and both were badly crushed and broken. $\mathrm{C}$ and $\mathrm{D}$ were pressed against each other. $\mathrm{E}$ and $\mathrm{F}$ were inside the bucket, and one side of $\mathbf{E}$ was crushed against the iron hoops. The three bucket-hoops had with the decay of the wood collapsed one upon another, the metal was heavily corroded and much broken. The ashes and calcined bones had been placed in the bucket and were unusually numerous. One fibula lay in the bucket on the surface of the bones, wood ash and earth which it contained, and near it was a shapeless lump of bronze probably representing some ornament melted during the burning of the body. The second fibula was found at the bottom of the bucket under the ashes, etc. The bucket must have originally been about $2 \mathrm{ft}$. $6 \mathrm{in}$. in diameter, but there was no evidence to indicate its height, all the woodwork having perished. The iron hoops were heavily rusted and were broken into many small fragments, but appeared 
to have measured three-quarters of an inch, an inch, and an inch and a quarter in width respectively, and about one-eighth of an inch thick. They had been fastened to the wooden staves by iron nails or rivets. Two circular drop-handles were attached to one of the iron hoops (pl. II, fig. 2). A bucket of this type measuring some forty inches in diameter was found at Aylesford (Arch. lii, $319)$. $^{\mathrm{T}}$

I4. Depth of grave 24 in. below present surface. It contained a pedestal urn ( $\mathrm{pl}$. Vl, no. I), in which were a few calcined bones. The urn was kept in place by large flints wedged against its pedestal and resting on its foot-ring. The upper part was much broken, having probably been hit by the plough.

15. The bottom of this grave was just over 12 in. below the present surface. It contained :

(A) A bowl (pl. VIII, no. I6), empty.

(B) An urn (pl. IX, no. 33), containing traces of calcined bones.

(c) A bowl (pl. IX, no. 35), empty.

The three vessels were touching each other. It would seem that in the process of hop planting $\mathrm{A}$ had been broken in fragments, в damaged and partly removed, but $\mathrm{c}$ escaped untouched.

I6. Bottom of grave $\mathrm{I}_{4}$ in. below present surface. It contained a few fragments only of a pedestal urn (not illustrated) of black ware, well made and burnished; with these were some calcined bones.

I 7. Grave dug 9 in. into gravel, $2 \mathrm{ft}$. in diameter. It contained :

(A) An urn (pl. VIII, no. I2), in which were a few calcined bones.

(B) A beaker (pl. VIII, no. I 9).

These were close together and were badly crushed and broken.

18. Diameter of grave $2 \mathrm{ft}$. $8 \mathrm{in}$, , bottom of grave $2 \mathrm{ft} .9$ in. from present surface, I $\mathrm{ft}$. in gravel. It contained :

(A) A wide-mouthed corrugated urn (pl. VIII, no. II), in which were calcined bones.

(в) A beaker (pl. VII, no. 9).

(C) A bowl (pl. IX, no. 24).

(D) A bronze fibula (pl. XII, no. 2).

(E) " " similar type.

(F) A small fragment of bronze.

x Two hoops of iron. presumably belonging to a bucket. were found with a cremated burial near Old Warden (Beds.): C. Fox, Arch. Camb. Reg. 98. 


\section{REPORTS OF THE SOCIETY OF ANTIQUARIES}

The three vessels were practically touching each other, $A$ and $B$ standing upright, and c lying on its side (pl. III, fig. I). The two fibulae were lying outside $A$, an inch above its base, one 2 in. from its north side, and the other $I$ in. from the west.

I 9. Diameter of grave $3 \mathrm{ft}$., bottom $2 \mathrm{ft}$. $8 \mathrm{in}$. from present surface, I ft. in gravel. It contained :

(A) A pedestal urn (pl. VII, no. 8), in which were calcined bones.

(B) A pedestal urn, similar type.

(c) A fibula (pl. XIl, no. 5).

(D) " (pl. XII, no. 6).

The two urns were lying close together on their sides; both were very crushed and distorted, the pottery being in a very friable condition and turning to powder when touched. The two fibulae were lying in the soil on the west side of the urns about 5 in. from their feet.

\section{DESCRIPTION OF THE POTTERY. \\ Plates VI-IX.}

r. Pear-shaped pedestal urn with quoit-shaped foot, raised base, and out-bent rim. Four large low cordons on shoulder, the body divided into unequal zones by groups of girth-grooves. A cordon at the junction of foot and body.

Brown unwashed friable clay coated with a smooth clay slip of light brown colour.

Found in grave 14.

Very similar urns have been found at Aylesford and Shoebury (Arch. lii, 329, pl. VII, 5 ; British Museum, Early Iron Age Guide, 26, fig. 23), the base of the latter being of the same type (Colchester Museum, nos. 195-6, and pl. X, no. 6, of this Report).

Compare the bases of nos. $2,3,4$, 10.

See page 25.

2. Pedestal urn with slightly spreading lip, pear-shaped body divided into unequal zones by deeply impressed girth-grooves, a quoit-shaped foot with slightly raised base and a cordon at the junction of foot and body.

Thin hard brown clay coated with a soapy brown slip.

Found in grave 2 with type 5 .

Compare Aylesford, Arch. lii, p. 332, pl. VII, 5-7.

See no. I and p. 26. 
3. Wide-mouthed pear-shaped pedestal urn with slightly outbent lip. Cordon at base of neck and another above foot. Quoitshaped foot and slightly raised convex base.

Dark brown well-washed pasty clay throughout.

Found in grave 13 with types $4,22,23,25,26$, and two fibulae, pl. XII, no. 3 .

Compare Aylesford, Arch. lii, p. 330, pl. VII, 6 ; and Welwyn, Arch. 1xiii, p. 24, pl. III, I.

See the bases of nos. I, 2, 4, IO, and p. 24.

4. Similar type to no. 3 , but with slight variations.

Found in grave 13 with types $3,22,23,25,26$, and two fibulae, pl. XII, no. 3 .

See p. 24.

5. Pear-shaped pedestal urn with slightly spreading lip and wide mouth, cordon at base of neck, body divided into unequal zones by deeply impressed girth-grooves. The support or pedestal is of dice-box shape on a beaded foot with slightly concave base.

Underbaked smooth soft brown clay coated with brown slip.

Found in grave 2 with type 2.

This type closely resembles no. 2, but has the dice-box shaped pedestal, a feature that does not occur at Aylesford or Welwyn, but may be seen on some of the examples in the Colchester Museum, mostly from Lexden, one of which has a beaded foot.

See nos. 6, 7, and p. 26.

6. Pear-shaped pedestal urn with spreading lip. Dice-box shaped support on a slightly concave base. Cordon at base of neck, counter-sunk cordons and a girth-groove divide the body into six unequal zones.

Brown hard brittle clay with smooth slip of a darker shade.

Found in grave 7 .

See nos. 5, 7, and p. 26.

7. Pedestal support of the dice-box type decorated with deeply impressed girth-grooves and with a slightly concave base.

Hard dark brown clay coated with darker smooth slip.

Found in grave 4 with type $3 \mathrm{I}$ and fibula, pl. XII, no. $\mathrm{r}$.

This is very similar to an example in the British Museum, from the Champagne district (pl. X, no. 4).

The same type as nos. 5 and 6 but straighter sided. See p. 25 .

8. Pear-shaped pedestal urn with slightly outbent lip. Five cordons or corrugations on the shoulder, another on the stem, and a girth-groove about half-way down the body. Below the shoulder 


\section{IO REPORTS OF THE SOCIETY OF ANTIQUARIES}

the body is lightly grooved or scored with close-set horizontal lines. Heavy quoit-shaped foot with slightly raised concave base.

Thin hard brittle dark brown clay with darker slip.

Found in grave 19 with another urn of the same type and fibulae (pl. XII, nos. 5 and 6).

Compare no. I, but the base is more like those from Welwyn (Arch. lxiii, pl. III, I, 2) and Deal (pl. IV, fig. I, of this Report). See p. 25 .

9. Beaker with slightly outbent lip and a cordon at base of neck. Pear-shaped body with spreading foot and flat base.

Hard dark brown to black clay coated with smooth slip and polished.

Found in grave 18 with types $\mathrm{I}-24$ and two fibulae (pl. XII, no. 2).

Compare nos. 16, I 8 , and see p. 25.

10. Tall conical urn tapering to a quoit-shaped foot with slightly raised base. Beaded lip, and a cordon at junction of foot and body. Decorated in horizontal zones by bands of girthgrooves.

Smooth pasty dark brown clay with darker well-smoothed surface.

Found in grave 6.

The prototype of this is undoubtedly to be found in a common early Gaulish La Tène type, an example of which, from the Morel collection in the British Museum, is illustrated on pl. X, no. 3 .

Compare Colchester Museum Report, I 909, pl. III, from Billericay. See bases of nos. I-4, and p. 26.

I I. Wide-mouthed corrugated urn in the form of an inverted truncated cone with outbent lip. Seven well-defined rounded corrugations form the entire side of the vessel. It has a splayed foot and conical raised base with a pronounced omphalos.

Hard brittle brown clay coated with smooth brown slip of a darker shade.

Found in grave I 8 with types 9, 24, and two fibulae, pl. XII, no. 2 .

There are examples of this type from Aylesford (Arch. lii, 332 , pl. VIII, 7), and a small cup of the same form was found at Allington and is now in the Maidstone Museum.

See p. 25 . base.

I2. Olla with bead lip, cordon at base of upright neck, flat 
Dark brown brittle clay coated with smooth slip of a darker shade.

Found in grave 17 with type 19.

There is a very similar example, but with two cordons at base of neck, from Deal, and now in the Deal Museum.

Compare Hengistbury Head Report, pl. XVIII, 29.

See nos. I 3, I 4, and p. 26.

I3. Olla-shaped beaker, the neck and lip missing ; these are restored in the drawing from nos. I2-I4. A cordon at base of neck and flat base.

Thick unwashed and underbaked brown clay, coated with dark brown smooth slip.

Found in grave 3 .

See types I 2, 14, and p. 26.

I4. Olla-shaped beaker with bead lip, a cordon at base of upright neck, high rounded shoulder and flat base.

Unwashed brown clay, rough inside, coated outside with. smooth slip.

Found in grave 8 with types 18,30 .

See types I 2, I 3, and p. 26.

15. Wide bulged urn with slightly outbent lip, a cordon at base of neck, and slightly concave base.

Underbaked dirty brown clay coated with soapy slip.

Found in grave I with fibula (pl. XII, no. 4).

Compare urns from Aylesford (Arch. lii, 332, pl. VII, 3, and Hengistbury Head Report, pl. XVIII, 29).

See p. 26.

I6. Wide bulged bowl with nearly upright rim, a cordon at base of neck, and slightly concave base.

Unwashed dark brown clay coated with darker pasty slip.

Found in grave 15 with types 33,35 .

There is a bowl of similar type, found at Colchester, in the Colchester Museum.

See p. 26.

I 7. Boldly outbulged olla with beaded lip, inbent neck with cordon at its junction with body. Flat base somewhat thickened towards the centre.

Hard brittle unwashed brown clay with darker smooth slip coating.

Found in grave 9 with types $2 \mathrm{I}, 29$.

Compare Arch. lii, pl. VII, 3, p. 332.

There are examples of this type in Maidstone Museum from 
Allington, Kent, in Deal Museum from Deal, and in Colchester Museum from Great Wakering (Colch. Mus. Report, 1922, pl. II, $3997,20)$.

See p. 26.

18. Beaker with cordon at the base of an upright neck with plain lip. Debased pear-shaped body with slightly concave base.

Smooth dark brown to black clay coated with well-polished slip.

Found in grave 8 with types 14,30 .

Although this is taller and thinner than no. 16 it has several similar features.

Compare no. 9, and see p. 26.

19. Biconical beaker with pigeon-breasted inside rim, five cordons on the shoulder, a flat base.

Dark brown brittle clay coated with a smooth darker brown slip.

Found in grave 17 with type 12.

Compare Aylesford (Arch. lii, 33 I, pl. VIII, 6). See p. 26.

20. Large-mouthed bowl-shaped urn with S-shaped side and a slightly concave base. On the shoulder is a zone decorated with oblique parallel scored lines, and, separated from it by two girth-grooves, a chevron pattern formed of pairs of scored lines.

Underbaked dark brown clay with darker brown slip.

Found by the gravel-diggers before the excavations were begun.

No exact parallels to this example appear to be recorded. See p. 27. base.

2 I. Globular beaker with bead lip and offset on shoulder. Flat

Hard smooth dark brown clay coated with smooth slip.

Found in grave 9 with types 17,29 .

A slight variation of this type in different technique occurs in the Roman period (Wroxeter Report, 1912, 71, fig. 17, no. 28). See p. 26.

22. Small bowl or cup with S-shaped side, spreading lip, a cordon at base of neck, a corrugation on the shoulder, a foot-ring and slightly raised base. Decorated below the bulge with a zone of narrow girth-grooves or striations.

Soft brown unwashed clay coated with brown slip.

Found in grave 13 with types $3,4,23,25,26$, and two fibulae (pl. XII, no. 3).

Compare cups from Hitchin, Shoebury, Welwyn, and Deal (Brit. Mus. Early Iron Age Guide, 26, figs. 22-3; Arch. lxii, 24, pl. III, 4, and pl. IV, fig. I, of this Report).

See nos. 23-5, and p. 24 . 
23. Similar type to no. 22, but without the striations.

Found in the same grave. See p. 24.

24. Similar type to nos. 22 and 23 , but with one girth-groove near base.

Found in grave 18 with types $9-\mathrm{I}$ I and two fibulae (pl. XII, no. 2). See p. 25 .

25. Similar type to no. 22, but without the striations.

Found in grave 13 with types $3,4,22,23,26$, and two fibulae (pl. XII, no. 3). See p. 24 .

26. Small bowl or cup with S-shaped side and outbent lip. Two faint cordons or corrugations on the upper nearly vertical portion. Flat base.

Hard dirty brown to smoky black clay, coarse and brittle apparently from overbaking.

Found in the same grave as the last.

See remarks to no. 22. See p. 24.

27. Nearly biconical cup or beaker with rolled lip and flat base. A cordon below the lip, another above the bulge, and a girthgroove below.

Thick heavy dark brown clay.

Found in grave 5 with types 28,34 .

Compare Aylesford (Arch. lii, 332, pl. IX, 3). See p. 26.

28. Small bowl or cup with rolled rim and a flat base.

Unwashed brown clay coated with darker brown smooth slip.

Found in grave 5 with types 27,34 .

Compare Hengistbury Head Report, pl. XXIII, 3; pl. XXVI, 6.

See also remarks on no. 29. See p. 26.

29. Globular bead-rim bowl, thick-sided on a flat base.

Hard heavy smooth dark brown clay, coated with smooth slip of a darker brown.

Found in grave 9 with types 17,21 .

Parallel examples have been found at various places such as Hengistbury Head (Report, 47, pl. XXIII, 3, 4), Oare, Wiltshire (Wilts. Arch. and Nat. Hist. Mag. xxxvi, I 25, pl. IV c), Puttenham, near Guildford (Surrey Arch. Coll. xxiii, 200), Woodcuts Common and Rotherley (Pitt-Rivers, Excavations in Cranborne Chase, xi, pl. XXXIII, 4, 5 ; ii, CVII, 2). See p. 26.

30. Small thick-sided biconical cup on a thin flat base. Three girth-grooves on the upper section.

Coarse dark brown clay smoothed on the outside.

Found in grave 8 with types $14,18$. 


\section{I4 REPORTS OF THE SOCIETY OF ANTIQUARIES}

There is a very similar cup, found at Colchester, in Colchester Museum. See p. 26.

3I. Olla-shaped urn of wide proportions with rolled rim, and three cordons or corrugations on the shoulder. The body is decorated with arched furrows made with a comb or bunch of twigs, and scored with a rough incised chevron pattern. A slightly concave base.

Soft brittle unwashed underbaked clay coated with a darkbrown slip.

Found in grave 4 with type 7 and the fibula (pl. XII, no. I).

Similar urns were found at Aylesford (Arch. lii, 33 I, pl. VIII, 6, pl. IX, 6).

A fragment with this type of decoration was found at Hambledon, Berks. (Arch. lxxi, i 8 I, fig. 16, no. 173).

Somewhat similar ware, with scored or furrowed decoration, also occurs at Richborough in first century A. D. deposits. See p. 25.

32. Narrow-necked olla with spreading lip and two low cordons or corrugations at juncture of neck and body. A slightly concave base. slip.

Soft friable brown clay, reddish at core, with smooth brown

Found in grave II.

Compare Aylesford (Arch. lii, 33 I, pl. IX, 7).

There is a very similar example from Colchester in Colchester Museum. It is recorded to have been found in association with a small bronze cup decorated with coral on the handle (Proc. Soc. Ant. xx, I23). See p. 27.

33. Olla with turned-in rim grooved on the top to support a lid, bulged body with two faint cordons or corrugations on the shoulder. Flat base.

Hard brittle clay, black at the core, coated with light brown slip on the inside and darker outside.

Found in grave 15 with types 16,35 .

Compare Hengistbury Head Report, pl. XXVI, 7.

A bowl with a similar type of rim was found in a grave group at St. Audebert, Canton Braisne, Aisne, associated with a pearshaped pedestal urn, two iron brooches of the late first century B. C., and other objects (Album Caranda, nouv. sér., pl. I I 3). There are also four vessels with rims of this description in Colchester Museum from Billericay, Braintree, Colchester, and Southminster, and one from Sandy, Bedfordshire, in the British Museum. See p. 26. 
34. Butt-shaped beaker with overhanging thickened and undercut rim smoothed and bevelled on the inside surface. Decorated on the bulge with two zones of rouletting bordered by girthgrooves and divided by a faint cordon. A slightly concave base.

Hard brittle dark brown clay coated with smooth slip.

Found in grave 5 with types 27,28 .

This type occurs at Aylesford (Arch. lii, 330, pl. IX, I), at Silchester (May, Silchester Pottery, I 68, pl. LXX, 154), at Mont Beuvray (Fouilles du Mont Beuvray, Album, pl. XXIV, 3), at Colchester (Colch. Mus. Rep., I 920, pl. II), at Wroxeter (Report, iii, I 9 I 4, pl. XXVII, 7 I, with a coin of Faustina II).

Compare Hofheim, I9I 2, pl. XXVI, IO2 (A. D. 40-51).

Other examples of the La Tene III period have been found at Folkestone (pl. XI, no. 5) and at Deal, p. 18, and are now in the museums at those places. See p. 26.

35. Wide-mouthed bowl or dish of truncated cone form, with nearly straight sides, unusually thick base and high foot-ring.

Soft pasty underbaked clay, black at the core, dark brown on the surface.

Found in grave 15 with types 16,33 .

Compare Glastonbury Lake Village, pl. LXXV, nos. 2, Io, which, however, have no foot ring; also Alter. u. h. Vor., v. Taf. 5 , no. 932 . See p. 26.

\section{Continental Prototypes and Parallels.}

Sir Arthur Evans, in his paper on the Aylesford urn find (Arch. lii, p. 3 r 7), has described fully the development of this class of pottery from its metal prototypes and has traced these characteristic types from their Illyro-Italic source through Gaul to this country, and it will serve no useful purpose to repeat here the evidence which he has so conclusively set forth in support of this.

To arrange the different types of this class of pottery in precise chronological order according to form or technique is a practical impossibility with our present knowledge. There are many different forms, but the earlier, as would be expected, are nearer to their metal prototypes and are cleaner cut and more angular than the later examples. The later are also not of such a fine clay, and the surface is not so highly finished as that of their predecessors. The difference in technique cannot easily be explained in words, but it is very obvious to the eye, and a comparison of the examples from the Aisne and Marne on the one hand, and from Aylesford and Welwyn on the other in the British Museum, will at once reveal the strong family likeness but also the distinct difference in 


\section{I6 REPORTS OF THE SOCIETY OF ANTIQUARIES}

technique and the variations in form. Besides these differences between the British and Gaulish examples it should be noted that some of the latter, such as the tall urns with sharply carinated bodies, do not occur at all in the British series (Brit. Mus. Early Iron Age Guide, pl. IV, I 2). This type has also a high, hollow foot, which is generally a sign of early date. This feature also occurs in the early pear-shaped pedestal urns and some other types (Brit. Mus. Early Iron Age Guide, pl. IV, I I, I 2). It appears to have developed from a type of foot like that belonging to the urn illustrated on pl. X, no. I, which is in the British Museum (Morel collection) and may be assigned to the earliest $\mathrm{La}$ Tene period. Some of the early bases also assume a more elegant form as in pl. X, 2, 3, which are also in the British Museum. Another good example from Somme Bionne is illustrated in the British Museum Early Iron Age Guide, 66, fig. 57. It will be seen that none of the Swarling examples has such a high, hollow foot, though several have this feature in a very modified form, and it appears certain that the cavity gradually diminished during the $\mathrm{La}$ Tène II and III periods until the base became practically flat, or only slightly concave, as in the examples from Colchester (pl. XI, no. I) and Allington (pl. XI, no. 7). This feature alone is not, however, a certain criterion of date. Some of the early $\mathrm{La}$ Tène vessels have flat, or practically flat, bases, while the tazza-shaped vessels of the La Tène III period such as those from Shoebury (Brit. Mus. Early Iron Age Guide, 26, fig. 23), have a high hollow pedestal, a feature which is also found on a few of the late pear-shaped urns of which there are examples in Colchester Museum, one of which is illustrated on pl. X, no. 7 (Colch. Mus. Rep., 1905, 85 I, p. 16).

The elaborate patterns as shown on the Gaulish types (Brit. Mus. Early Iron Age Guide, 46, pl. IV, nos. I, 7, IO, and Arch. lii, pl. XII, I to 4) do not last into the La Tène III period in this country, although the crude scored decoration on certain vessels such as those from Aylesford (Arch. lii, pl. IX, 5, 7, 8) is probably a reminiscence of this. The use of red pigment in the decoration of some of the early continental examples is another feature which is absent in the later British series.

Sir Arthur Evans states that the Aylesford urn-field may be assigned to the period that preceded the Roman invasion of Britain, its immediate antecedents being found in the Belgic parts of Gaul. The place, therefore, where we would expect to obtain some good evidence of the date of the British types should be in France, and the St. Germain Museum, which contains a wonderful collection of urns mostly from the Aisne and Marne districts, was visited with 
that object in view. Unfortunately this great mass of pottery, although bearing a distinct family resemblance to the SwarlingAylesford series, is earlier in date, belonging to the periods of La Tene I and II. The museum authorities, when shown the drawings of the Swarling urns, were very definite in their opinion that they were not earlier than La Tène III, and the general impression conveyed was that the British examples were at least one stage later than the great bulk of the Gaulish. It should also be noted that in France the majority of the burials with this type of pottery are inhumations, a common practice in $\mathrm{La}$ Tene I and II, whereas cremation was practically universal in La Tène III (Déchelette, Manuel, iii, IO22). The fact that all the burials recorded in this country with the Swarling types are cremations, justifies their attribution to La Tène III. Sir Arthur Evans tells us that close parallels to the Aylesford pottery have been found near St--Valéry-sur-Somme, at Belozanne in the district of the Lower Seine at Moulineaux, near Rouen, and in the neighbourhood of Worms (Arch. lii, 340, 383). A good example of a late pear-shaped pedestal urn is recorded from St. Audebert, with which was a fibula that can hardly be earlier than the late first century B.c. (Moreau, Album Caranda, pl. I I 3). There are also in the St. Germain Museum La Tène vessels from the last-mentioned place, Celles (Cantal) and Bruney, some of which are pear-shaped pedestal urns with practically flat bases. Several vessels of the same type and very similar to the British examples, especially certain specimens from Colchester, are exhibited in the museum under the heading of Gallo-Roman, or roughly after 50 в.c. It will be seen, therefore, that little assistance in the closer dating of the British examples than La Tène III, and some of them probably to the latter part of it, can be obtained from France. Finds of this period in England have not by any means always been adequately recorded, and well-authenticated associated datable objects are lamentably few in number. The following short summary of the most important discoveries connected with the Aylesford-Swarling types provides, however, some useful evidence of their date and distribution.

\section{Aylesford.}

Sir Arthur Evans gives the middle of the first century B.c. as the chronological centre for the Aylesford cemetery, but states that some of the later graves probably come down appreciably nearer the Claudian conquest than that date (Arch. lii, 382). What was probably one of the earliest graves in that cemetery contained 
a bronze patella and oenochoè which he believes to have been made in Italy in the second century B.c. and which were not likely to have been deposited in the grave later than the first half of the following century (Arch. lii, 380). Associated with them were two fibulae, both imperfect but of the same type as those from Swarling (pl. XII, no. 3). Sir Arthur Evans places these fibulae in the first half of the first century B.c. (Arch. lii, 382).

There were also in this grave-group two fine cordoned pearshaped pedestal urns and a corrugated vessel, Swarling type I I. This last was found at Swarling with a fibula (pl. XII, no. 2) that does not appear to be as early as the Aylesford examples, and it is doubtful if this early Aylesford group can be placed much earlier than the second quarter of the first century B.c. That the Swarling and Aylesford urn-fields are of the same period is shown by the great similarity of many of the types from the two sites. The tall pear-shaped pedestal urns are represented at both places, and although no two urns of this particular class ever appear to be exactly alike, type I from Swarling and the Aylesford example (Arch. lii, pl. VIII, 5) are so nearly akin that either might have served for the model of the other. Type 3I from Swarling with the furrowed or combed pattern is of the same class as the example from Aylesford (Arch. lii, pl. VIII, 6). Type 34 is closely allied to Aylesford (Arch. pl. IX, I), as is 17 to pl. VII, 3 ; and 27 to pl. IX, 3. There are no types at Aylesford that have earlier characteristics than those at Swarling, and it seems probable from the evidence now collected that the chronological centre for the former urn-field, placed by Sir Arthur Evans at about 50 в.c., may be some thirty years later.

\section{Deal.}

In the small museum at Deal there is a very interesting collection of this pottery among which are two well-authenticated grave-groups with fibulae. The first of these, illustrated on pl. IV, fig. I, contained a fine pear-shaped pedestal urn with heavy, splayed, practically flat base, somewhat similar to Swarling type 8, three small cups, one with a pronounced kick or omphalos in the base, a jar with slightly raised cordons or corrugations on the body, a dish of a type similar to some examples from Mont Beuvray in the St. Germain Museum and two fibulae (pl. XIII, nos. 7, 8, and p. 43). These fibulae are not early in La Tène III. No. 7 has some features in common with both the Swarling examples (pl. XII, nos. 2, 5, from grave-groups II and 19), while no. 8 is of the same type as no. 4 from grave-group 1 . Pedestal urns with the flat heavy splayed base appear at Swarling to be late in the series 
(pl. VII, no. 8), and the Mont Beuvray type of dish should not be much after 5 B.c., the date of the end of that site. It would seem therefore that this group belongs to the late first century в.c. or early first century A. D.

The second group is illustrated on pl. IV, fig. 2, and contained a barrel-shaped cordoned urn, two cups somewhat similar to those in the last group, fragments of a large dull-red vessel with reeded handles, and the fine fibula (pl. XIII, no. 9 and p. 43). This fibula belongs to the same class as those in the previous group, and cannot be far removed from them in date. In this grave was also found the set of toilet implements (pl. IV, fig. 3), which are very Roman in appearance. Toilet sets of the La Tène period, although somewhat different in character, have, however, been found on the Continent (Déchelette, Manuel, I 27I).

Among other pottery vessels in this collection are three pearshaped pedestal urns with practically flat bases; Swarling type $\mathbf{I} 7$ in red clay with a foot-ring, and an example similar to Swarling type I 2, but with two low cordons at base of neck.

The fibulae illustrated on pl. XV, no. 16 also came from the same urn-field. They are all La Tène III types, but have earlier characteristics than the other fibulae from this site. See p. 44.

Taken as a whole the finds from this urn-field are very similar to those from Swarling and Aylesford, and must therefore belong to the same period. I have to thank Mr. C. K. Rhodes for drawing my attention to these objects and for obtaining the photographs for me. Mr. S. Manser of Deal has also given considerable assistance.

\section{Allington.}

In Maidstone Museum there is a collection of pottery from Allington, Kent, which includes the following Swarling types :

I 7, but smaller in size, found with $2 \mathrm{I}$ and 29 at Swarling and probably late in that series.

9, but with more outbent rim and of hard grey clay approaching Roman technique.

I2, but rim not quite so outbent.

I I, in miniature, being only $2 \frac{3}{4} \mathrm{in}$. high, $4 \frac{1}{2} \mathrm{in}$. in diameter at the mouth, and $2 \frac{1}{2}$ in. in diameter at the base, which is flat. It has four corrugations, not counting the rim and base mouldings.

I 3-I4. Three examples, all of which were used as cinerary urns. Also, among others, a degenerate pear-shaped pedestal urn with flat base. A cordoned cup with hollow foot of Mont Beuvray type (Bulliot, Mont Beuvray, pl. XXVIII, 7). A large open dish very similar to one from the last-named site in the St. Germain 
Museum. With these were found two or three fibulae of the type pl. XV, no. I4, which may be assigned to the first half of the first century A.D. (pp. 44, 45).

There is also a well-attested burial group from the site consisting of the cordoned urn (pl. XI, no. 7) of hard brown clay with a smoothed surface, the plate (pl. XI, no. 8) of the same ware with an imitation stamp and, obviously, a local copy of a Belgic plate, and the fibula illustrated on pl. XV, no. I 5 (see p. 44). It is not likely that this group can be earlier than the second quarter of the first century A.D., and the whole of the Allington finds would appear to be later than the beginning of the Christian era.

I am indebted to Mr. Elgar for the information concerning these finds and for the drawings and photographs of the objects.

\section{Folkestone.}

Three interments of considerable interest were recently found by Mr. C. H. Stevens, who has supplied me with the particulars of the discovery, in his allotment near the angle formed by Julian Road and Wilton Road, Folkestone. There were three burials, two close togrether, and the third some $46 \mathrm{ft}$. to the south-east. This last grave only contained one urn (pl. V, fig. 2, and pl. XI, no. 5) of biscuit colour, fine, thin, well-levigated clay with smooth surface ornamented with bands of rouletting. It contained burnt bones and the fibula (pl. XIV, no. Io and p. 43) with perforated catchplate of La Tène III type, not earlier than the late first century в. c., and very probably first century A. D. One of the other burials also consisted of only one cinerary urn of hard gritty clay, grey mottled to light brown with a darker surface coating and decorated with bands of incised vertical lines, rather irregular, but possibly made with a roulette (pl. V, fig. 3, and pl. XI, no. 4). The third group was of more than usual interest, as itconsisted of a small pedestal pear-shaped urn (pl. V, fig. I, and pl. XI, no. 6) of grey to light-brown clay with well-smoothed surface, a Roman jug of coarse, badly-levigated lightred clay containing small particles of grit (pl. V, fig. I), and a Samian cup, shape 27 (pl. V, fig. I). The pedestal urn contained burnt bones and the fibulae (pl. XIV, nos. I I, I 2), both of which were imperfect, but appear to be first century A.D. types (pp. 43-45). The Samian cup has no particularly early characteristics and may well have been made at $\mathrm{La}$ Graufesenque and belong to the middle or second half of the first century A.D. The jug is a poor badlymade specimen, and typologically should not be earlier than the second half of the first century A.D. This group may be dated with some certainty not earlier than the middle of the first 
century A.D. and may well be later. ${ }^{x}$ I am indebted to Mr. C. K. Rhodes for furnishing me with the photographs and the drawings of these objects.

\section{Colchester and other Places in Essex.}

A fine collection of pottery of this type is in Colchester Museum, but associated datable objects are lamentably scarce. A group from Great Wakering includes a small pedestal urn with a base of very similar type to the example from Deal (pl. IV, fig. I, and p. I 8). With the group was associated part of a bronze fibula with a flat-ribbed bow and cylindrical spring cover which cannot be earlier than the first century A. D. (Colch. Mus. Rep., I 922, pl. III). A find of associated pottery from Heybridge includes cordoned urns and part of a large Arretine plate, which is not likely to have reached this country before the time of Augustus. The foot of a pear-shaped pedestal urn, a bead-rim bowl, several fragments of vessels with horizontal striated lines and an imitation Belgic platter with low base-ring (Mus. no. $442 \mathrm{I}$. 23) which are in the museum, were recently found at Braintree and may be assigned to the first half of the first century A.D. A pear-shaped pedestal urn (Mus. no. 76, 97) found in Colchester is in pure Roman technique, being made of a dull red clay coated with a light buff slip. It has a high hollow base, with decorated cordon on a moulded stand-plate (pl. X, no. 5), and is a good example of a Roman imitation of this particular type and can hardly be earlier than the Claudian invasion of 43 A. D. The upper part of an amphora of thin red ware with buff exterior and two reeded handles, probably not earlier than the beginning of the Christian era, was found with a pedestal urn (Colch. Mus. Rep., I905, 85 $1-2)$, which although it has a high hollow foot (pl. X, no. 7) has no other early characteristics, the foot being of the same type as those of the tazza class, such as the examples from Welwyn (Arch. lxiii, pl. III, 3) and Shoebury (Proc. Soc. Ant. xvi, 259). One group lately found at Lexden is of exceptional interest as the association of the various types is well authenticated. The group contained a large pearshaped pedestal urn of the usual dark brown late Celtic fabric and with a nearly flat base. It is illustrated on pl. III, fig. 2, and $\mathrm{pl}$. XI, no. I, but it was found impossible to obtain a section of the interior of the pedestal as this part of the urn had been

- A further find of Late Celtic urns containing cremated burials and associated with two La Tène III fibulae, one of silver and similar to that from Great Chesterford, Essex (B.M. Early Iron Age Guide, 10 I, fig. 83), has recently been discovered at the Warren, Folkestone, by Mr. Winbolt (Ant. Jour. v, 65). 


\section{REPORTS OF THE SOCIETY OF ANTIQUARIES}

filled with cement when mended. The other vessels consisted of two small carinated cordoned cups (pl. III, fig. 2, and pl. XI, no. 3), a tall, butt-shaped urn and a Roman jug of reddish clay (pl. XI, no. 2). Very similar jugs have been found at Hofheim (type $50 \mathrm{~B}$ ), where they belong to the 40-5 I A.D. occupation (Ritterling, Hofheim, p. 360, pl. XXXIV). The rim of the Colchester example is, however, not undercut as are the Hofheim examples, which probably indicates a slightly later date, and it would seem that the group must have been deposited at a date later than the Claudian invasion in 43 A.D.

A close parallel to the carinated cups in the last group (pl. XI, no. 3) was found at Kelvedon, Essex, and is now in the British Museum. The Kelvedon example (pl. XI, no. 9) has, however, a small foot-ring not unlike those on the red and black Belgic plates of the Augustan-Claudian period. In association with it was found the fibula (pl. XIV, no. 13) which may be assigned to the first half of the first century A.D. (pp. 44, 45).

One of the finest groups in this museum, illustrated in Proc. Soc. Ant. xx, 21 3, was found within the borough of Colchester, and consists of a bronze mirror, a bronze cup with coral decoration on the handle, two jugs with reeded handles, a cordoned bowl with cover, a vessel very similar to Swarling type 32, a small cup with corrugations on the shoulder and a tine plain, pear-shaped pedestal urn. These are said to have been found in association, and an early date has been assigned to them because of the presence of the coral decoration on the bronze cup, as this particular type of ornament is not generally believed to be much later than the third century B.c. A clue to the late date of the pottery in this group is, however, afforded by the pear-shaped pedestal urn, which is practically identical with that from the Lexden group mentioned above (pl. XI, no. I) which can be assigned to a period after the Roman. occupation of this island under Claudius. These two groups cannot therefore be separated by any considerable space of time, and the use of coral decoration must either have continued longer in this country than is usually accepted, or the bronze cup must have been deposited in the grave, as were the Aylesford bronzes, a very considerable time after the date of manufacture. The Birdlip mirror, which has been assigned to the first century A. D. (Arch. lxi, 345) and belongs to the same class as the example in this group, is additional evidence of its late date.

There are many types in the Colchester collection which are very similar to those from Aylesford and Swarling. The bases of the pear-shaped pedestal urns are in some cases of the same character, notably that of the fine urn from Shoebury (pl. X, 
no. 6) and Swarling types $\mathrm{I}$ and $\mathrm{I} 0$, which are certainly early in the series, but the majority of the Colchester examples have practically flat bases, and the types believed to be early at Swarling and Aylesford are not so well represented. There is not a single example that belongs to the same class as the $\mathrm{La}$ Tène I and II specimens from the Aisne and Marne, in fact there appears to be a considerable gap between the two series, and the great bulk of the Colchester Museum pottery may be placed between 50 B.c. and $50 \mathrm{~A} . \mathrm{D}$. Mr. Wright, curator of the museum, gave me great assistance and every facility in examining the collection, and I have to thank him for the photograph of the Lexden group and the drawings of some of the pottery, Dr. R. E. M. Wheeler having very kindly made those of the remainder.

\section{WELWYN.}

The pottery types found at Welwyn (Arch. 1xiii, pl. III) and now in the British Museum are closely allied to some of the Colchester examples and cannot differ much from them in date. The three pear-shaped pedestal urns are without cordons or girthgrooves, features that appear to be more common north of the Thames than south of it on this particular shape, and their bases are practically flat (Arch. lxii, 24, fig. 22). It is to be regretted that the exact association of the metal objects and the pottery from this site is uncertain. The silver kylix handles may be as early as 300 B.c. or earlier if they belonged to a cup of the type illustrated in the paper, but they may equally as well have been attached to a vessel with a plain foot-ring instead of the pedestal, which would be very considerably later in date. The two silver cups are not easy to date as no exact parallels to them can be traced. They are, however, not far removed in form from some of the Arretine shapes, and might well belong to the period of Augustus. The patella has been assigned to the second century в.c. It is very difficult to estimate the length of time these metal objects may have survived in use in this country in prehistoric times. The date of manufacture and the date of deposit in a grave may have been separated by a very considerable period, as it is more than probable that these articles were considered great luxuries and as such were highly prized, carefully preserved, and handed down as heirlooms from father to son. In any case, whatever may have been the date of the manufacture of these metal objects, their date of deposit, if they occurred in association with the pottery from this site, cannot be before 50 B.c. and is probably several decades later. 


\section{REPORTS OF THE SOCIETY OF ANTIQUARIES}

\section{Hauxton.}

A barrel-shaped cordoned urn and a vessel of similar type to Swarling 34 and that from Folkestone (pl. XI, no. 5) were found with a fibula of Augustan-Claudian type at the above place, which is near Cambridge (C. Fox, Arch. Camb. Reg. 91, and pl. XIII).

\section{Duston.}

There is an interesting group of this pottery in the Northampton Museum from a cemetery a little to the west of that town at Duston. Among other specimens in the collection are two late pear-shaped pedestal urns and a number of cordoned and corrugated vessels, a common type being a straight-sided cup not unlike the Samian form 30. This pottery may be placed late in the series, and although closely allied to the Kentish examples has some characteristics not met with in that county. The collection from Duston also includes Belgic plates, local imitations of these and a number of fibulae, the earliest specimens, of which there are about a dozen, being of the Allington type (pl. XV, nos. I 4, I 5). If these plates and fibulae came from the same cemetery as the Late Celtic pottery, they would date it with some certainty not earlier than the first half of the first century A.D. There was, however, a Roman site in the vicinity and unfortunately the finds from both sites are only marked Duston in the museum, and there appears to be no record from which site these plates and fibulae came.

\section{WEEKLEY.}

1 am informed that there is a very similar group of pottery to that from Duston but possibly even later in date in the Kettering Museum from Weekley. I have seen a coin of Tasciovanus (the end of the first century B.c.) which was discovered on the site.

The dating of the Swarling Pottery. ${ }^{\mathrm{x}}$

The chronological evidence reviewed above is fully confirmed and augmented by the finds at Swarling, and also helps materially in dating some of the objects from this cemetery.

At Swarling there were five grave-groups that contained fibulae. In group 13 were the two fibulae type 3 , and associated with them were the pottery vessels $3,4,22,23,25,26$. This group is probably one of the earliest from the site, as these two fibulae are of the same type as those from Aylesford (p. I 8) and according to Sir Arthur Evans should be before 50 B.c.

1 Detailed descriptions of the Swarling types will be found on pp. 8-15. 
Grave-group I 8 contained the vessels II, 24, and 9, and two fibulae of type 2. The cup 24 is similar to types $22,23,25$ in group I 3 just mentioned, and there should not therefore be much difference in date between the two graves. An example of type I I was also found in the grave-group at Aylesford in which were fibulae of type 3, thus affording another link between these two grave-groups. The fibulae type 2 are very similar to type 7 from Deal, and are probably later in date than type 3. The beaker type 9 , which appears to be a debased variety of a pear-shaped pedestal urn, also suggests a later date for this group than that assigned to grave I 3 , and probably belongs to the period 50-I B. C. Type I I from this group is an interesting specimen, as the very similar example from Aylesford (Arch. hi, pl. VIII, 7) and others from the same site are, with the exception of the small cup from Allington (p. r 9 ), the only examples of this type that can be found recorded. Just as the cordoned pear-shaped pedestal urns can be traced back to their metal prototypes, so can these corrugated pottery vessels, as they are obviously a clay version of the bronze ribbed buckets of the Hallstatt type which can be assigned to about the seventh century B.c. The Weybridge bucket is a good example of these and has nine ribs or corrugations not counting the lip and base mouldings (Proc. Soc. Ant. xxi, 464). The Swarling vessel has seven ribs, the Aylesford eight, and their bases have a pronounced kick or omphalos, a feature which is present in the Weybridge bucket and which may also be seen in a more exaggerated form in a bronze bucket from Zollnig, Silesia (Alt. u. h. Vorz., p. 326, fig. I.e. no. I025).

Grave-group I 9 contained two pear-shaped pedestal urns of type 8 and the fibulae types 5, 6. The latter Mr. Reginald Smith believes to be one of the latest from Swarling, and thinks that its date can hardly be earlier than the second quarter of the first century A. D. (p. 42). This therefore would place the urn type 8 late in the series, a conclusion that is borne out by the nearly flat heavily splayed foot which is undoubtedly a later development of types $\mathrm{I}-4$ and $\mathrm{r} O$. See bases of pedestal urns from Ieal (pl. IV, fig. I), Colchester (pl. XI, no. I, and pl. III, fig. 2), Great Wakering (Colch. Mus. Rep., 1922, pl. III).

Grave-group 4 contained urns type 7 and $3 I$ and the fibula type I. The base type 7 is similar to that of the urn (pl. X, no. 4) from the Champagne district now in the British Museum. M. Hubert of the St. Germain Museum when shown a drawing of this Gaulish example stated that it belonged to the La Tène III period. Mr. Reginald Smith places the fibula early in the Swarling series (p. 40), and the fact that the fragment 


\section{REPORTS OF THE SOCIETY OF ANTIQUARIES}

type 7 is well made and of good technique indicates also that this may belong to the early period, thus giving a clue to the date of type $3 \mathrm{I}$.

Grave-group I contained, as far as is known, only one urn type 15 and the fibula type 4. Neither the urn nor the fibula has any early characteristics and both certainly belong to the first century A.D., and are probably not far removed in date from the beginning of the Roman occupation of this country.

Of the other types from Swarling, nos. I and 1o with their raised bases are undoubtedly early in the series, and may well be the two earliest examples from the site. Type 2 has a base closely allied to types 3 and 4 of group 13 , mentioned above, and should therefore be of the same date. As type 5 was found associated with type 2 it should also belong to the same period. The bases of type 6 and type 5 are very similar and these two examples cannot be far removed in date.

Types 12, 13,14 are similar to examples from Allington (p. 19) and are certainly late in the series, that is to say in the first century A. D. Types 18, 19, 30 were in association with two of these types (I 2 and I4 $_{4}$ just mentioned, indicating that they belong to the same period.

Type 16 has some features in common with both type 9 (grave I8) and type I5 (grave I), and may therefore belong either to the late first century B.c. or the early first century A.D. As types 33 and 35 were found with it they should be of the same period.

Type 17 was found in association with types 21 and 29. Type 21 is approaching a Roman type (Wroxeter Report, i, fig. I 7, no. 28), and 29 is a good example of a bead-rim bowl, a type which, although occurring earlier than the Claudian invasion of this country in A.D. 43, being found with Mont Beuvray, Arretine ware and Belgic plates, also lasted well into the Roman period (Hengistbury Head Report, 47, pl. XXIII, 3, 4, and Arch. lxvi, fig. I 4, nos. I 2, I3, I 4, and pp. 248, 250). Type $\mathrm{I} 7$ is represented among the vessels from Allington (p. 19), and an example has been found at Great Wakering, Essex, and assigned to the period A.D. I-50 (Colch. Mus. Rep., 1922, 3997-20). It would seem therefore that these three vessels are not earlier than the first half of the first century A. D.

Types 27, 28, 34 were found in the same grave. Type 28 is a bead-rim bowl (see last paragraph) and type 34 a type which, with slight variations, has been found over a large area stretching from the Rhine to Britain; and although the earliest examples belong to the first century B.c. a specimen was found at Wroxeter with 
a coin of Faustina II A.D. I 4I-75. An example from Hauxton can be dated to the late first century B.c. or early first century A.D. (p. 24), while the example from Folkestone appears to belong to the same period (p. 20 and pl. XI, no. 5), which is probably about the date of these three Swarling vessels, nos. 27,28 , and 34 .

Type 32 was found by itself, and there is no evidence at Swarling for its chronological position in the series. Its similarity, however, to an example found at Colchester (p. 22) and said to have been found in association with a pedestal urn of the type (pl. XI, no. I) suggests that it should not be placed early in the series.

Type 20 was found by the gravel-diggers before the excavations were begun, and there is no definite evidence forthcoming as to its date.

\section{Summary of Dating Evidence.}

It will be seen therefore that the evidence obtainable from the Continent points conclusively to the La Tène III period for this particularclass of pottery in Britain. The evidence afforded by finds in Britain itself indicates that the greater part of this characteristic ware is after 50 B.c., and that some examples are as late as the early years of the Roman occupation of this country that began in A.D. 43 under the Emperor Claudius. ${ }^{\text {' The archaeological }}$ evidence for placing any of it before $5 \circ$ в. c. rests at present almost entirely on the fibulae of type 3 (pp. I 8, 4I). It should, however, be borne in mind that our knowledge of the exact date of some of the other fibulae is by no means certain, and although $\mathrm{Mr}$. Reginald Smith believes the earliest to be about $5 \circ$ B.c. (p. 45), some of them may be slightly earlier than that date, but none can possibly be before ro० B.c. (p. 46). With the available evidence it would therefore appear safe to place the earliest examples of the Aylesford-Swarling pottery not earlier than between 100 and 50 B. C., and probably rather after 75 B.c. than before it.

\section{The distribution of the Aylesford-Swarling type of Pottery in Britain.}

There is a very considerable amount of pottery of the Swarling type in south-east Britain, and the following is a list of some of the principal places at or near which it has been discovered, and where in all probability it was deposited by the people who made and used it.

\footnotetext{
I Some typical examples of this ware were found at Richborough in 1923 in association with Claudian Samian.
} 


\section{REPORTS OF THE SOCIETY OF ANTIQUARIES}

Kent.

Aylesford. In the British and Ashmolean Museums (Arch. lii, 3I7).

Allington. In Maidstone Museum.

Murston. In British Museum.

Rochester.

Folkestone. "In Folkestone Museum.

Deal. In Deal Museum.

Broadstairs. In the offices of the Town Council, Broadstairs (Proc. Soc. Ant. xxii, 259, and Arch. 1xi, 427).

Swarling. In the British Museum.

Essex.

Billericay. In Colchester Museum (Proc. Soc. Ant. xvi, 259).

Braintree. " " , (Ant. Jour. iii, I 48).

Colchester. " " " " (Colchester Museum Reports).

Great Wakering. In Colchester Museum (Colchester Museum Report, 1922, pl. II and III).

Great Chesterford. Audley End (Lord Braybrook's MS. Catalogue. C. Fox, Arch. Camb. Reg., 9 I, 92, 98).

Goldhanger. In Colchester Museum (Proc. Soc. Ant. xxii, 194).

Hamborough Hill, near Rayleigh. In Colchester Museum (Arch. 1xiii, 27).

Heybridge. In Colchester Museum (Arch. Ixiii, 28).

Kelvedon. In British Museum (Arch. lxiii, 25).

Langenhoe. In Colchester Museum (Proc. Soc. Ant. xxii, I 9 I).

Lexden. In Colchester Museum (Arch. Ixiii, 4).

Little Hallingbury. In Colchester Museum (Trans. Essex Arch. Soc. ix, 348).

Shoebury. In Colchester Museum (Proc. Soc. Ant. xvi, 258).

Southend-on-Sea. Southend Institute.

Southminster. Colchester Museum.

Wendens Ambo. In Walden Museum. (C. Fox, Arch. Camb. Reg., 98).

Wickham Bishops. In Colchester Museum (Colchester Museum Reports, I 9 I 8, 8, I 920 , pl. I).

Hertfordshire.

Abbots Langley. In St. Albans Museum (Ant. Jour. ii, 259).

Ashwell. In British Museum.

$\begin{array}{llll}\text { Hitchin. } & " & & (\text { Proc. Soc. Ant. xiii, 16). } \\ \text { Letchworth. } & " & " & (\text { Ibid. xxvi, 238). } \\ \text { Pegsdon. } & " & " & \\ \text { Welwyn. } & \text { Arch. Ixiii, I). }\end{array}$


Bedfordshire.

Arlesey. In British Museum.

Stotford.

Shillington. " " "

Cambridgeshire.

Cambridge and neighbourhood.

In Cambridge Archaeological Museum

(C. Fox, Arch. Cämb. Reg., 9 I ,9 2,93).

Barrington.

Guilden Morden

Haslingfield.

Hauxton.

Milton.

Whittlesford.

"

$\begin{array}{ll}" & " \\ " & " \\ " & " \\ " & " \\ " & \end{array}$

Nortbamptonshire.

Duston. In Northampton Museum.

Weekley. In Kettering

,

Huntingdonshire.

Alconbury. (C. Fox, Arch. Camb. Reg., ro3.)

Suffolk.

Long Melford. (C. Fox, Arch. Camb. Reg., 103.)

Sudbury.

Great Waldingfield. " " "

The bulk of this pottery has been found in Kent, Essex, and Hertfordshire, and it is evident that the people to whom it belonged did not penetrate westward, at any rate to any appreciable extent, beyond the forest of Anderida, into the midlands, or further north than Northamptonshire. ${ }^{1}$ In fact the finds outside this area, such as a tazza and a cordoned bowl at Rotherley (PittRivers, Cranborne Chase, ii, pl. CIX, fig. I, pl. CX, figs. I, 3), tazzas and a fine cordoned barrel-shaped urn at Rushmore (Pitt-Rivers, op. cit. i, pl. XXXV, figs. 5, 7), a tazza at Sare, Wilts. (Wilts. Arch. and Nat. Hist. Mag. xxxvi, 125), all found in association with much pottery of other types, would seem to indicate that the users and makers of this ware had little or no intercourse with the neighbouring tribes. The fact that the excavations on the site of Silchester, which was undoubtedly occupied before the end of the first century в.c., a period when this pottery was common in Kent and Essex, did not produce a single specimen of the most characteristic types is a very striking

I Dr. Cyril Fox in his Arcbacology of the Cambridge Region (102-104) states that the neighbourhood of Cambridge marks the northern limit of the Aylesford culture, and that it does not appear to have penetrated into the territory of the Iceni. 
example of this. Also at Hengistbury $\mathrm{Head}$, where there was evidence of a considerable occupation between roo B.c. and A.D. 50, only one fragment of a pedestal urn was met with (Hengistbury Head Report, pl. XXIII, fig. 20).

\section{Historical Conclusions.}

Having obtained an approximate date for the pottery and traced the area in which it occurs in this country, we may now glance briefly at the historical evidence for this period considered in conjunction with the archaeological, in order to ascertain if any conclusions of interest can be arrived at concerning the movement of tribes from the Continent to Britain and the date of their coming.

Julius Caesar, writing about the middle of the first century в.c., supplies us with much useful information, which however has been dealt with so often by various authors that a short summary will be all that is needed. His chief references to this country and its-connexion with the Continent are as follows :

I. Divitiacus had held the government of a great part of Gaul as well as Britain. B. G. ii, 4 .

2. Commius, whom Caesar set up as chief of the Atrebates

- in Gaul, had considerable influence with the Britons, and was sent over by him before his invasion to persuade as many states as possible to accept the protection of the Roman people. $B . G$. iv, 2 I .

3. Help had been sent to the Gauls by the Britons. in almost all the wars against the Romans. B. G. iv, 20.

4. The Veneti who were accustomed to sail to Britain sent there for support in their resistance to the Romans. $B . G$. iii, 8, 9 .

5. The Gauls came to Britain to study the mysteries of Druidism. B. G. vi, I 3 .

6. According to tradition the interior portion of Britain was inhabited by people who were born in the island itself, the maritime portion being peopled by those who had come over from the country of the Belgae for the purpose of plunder and conquest, and had remained there and begun to cultivate the land. Almost all of them bore the names of the tribes from which they came. B. G. v, I 2 .

7. The most civilized of the Britons were those who inhabited Kent, nordid their customs differ much from the Gallic. B.G. v, I 4 .

It would therefore appear that there was an intimate connexion between the two countries, and that tribes, or sections of tribes, had passed from Gaul to Britain and settled there before the time of Caesar. The detailed nature of the tradition reported by Caesar, however, that these people had gone over for plunder and making war, and after obtaining a foothold in the country 
had settled there and begun to cultivate the land, suggests that the invasion was of recent date and that it was not long before his time that the Belgic tribes had established themselves in Britain.

It is a curious fact that although Caesar expressly states that the tribes bore the same names as those in Belgic Gaul, he does not mention in the whole account of his operations in this country a single British tribe that is known to have inhabited that part of the Continent. This is the more surprising as on both occasions he landed in Kent, the nearest point to Belgic Gaul, which he tells us himself was the most Gallic district of Britain. Here if anywhere we should expect to hear of Belgic tribes and find this portion of the island bearing a Belgic name, but it was still Cantium as in the days of Pytheas some three hundred years previously (Strabo i, c. 4. 3). Caesar therefore does not help us to decide which tribes, or portions of tribes, had already entered the country before his time, and it will be necessary to see what light can be thrown on the subject from other sources.

The Atrebates, the Catuvellauni, and the Parisii are the only Belgic tribes that can be said with certainty to have been represented on both sides of the Channel. To these must be added the Belgae, who in Gaul were not a tribe but a confederacy of tribes. In Britain, in Ptolemy's time, about A. D. I 50, the latter appear to form a tribal canton to judge from the name of their capital Venta Belgarum (Winchester); but it is possible that this canton was formed from sections of various Belgic tribes of Gaul which had previously entered this country.

The other towns of the Belgae, according to Ptolemy (Geog. ii, 3 , f. I 3), were Ischalis (Ilchester ?) and Aquae Calidae (Bath), and their territory must have extended over a great part of Hampshire, Wiltshire, and Somerset. Had they occupied this area in Caesar's time they would hardly have come into contact with him, as they would have been separated by the great forest of Anderida from the scene of his operations. Now this area of the Belgae, and some of the immediately adjacent districts, is much richer in archaeological evidence of a connexion with the Continent in early $\mathrm{La}$ Tène and even late Hallstatt periods than is the south-eastern part of Britain, as has been shown by the finds at Hengistbury Head, All Cannings Cross, etc. (Hengistbury Head Report, 9). Also of the thirty-six La Tene I fibulae found in this country and listed by Mr. St. George Gray, fifteen can be assigned to Wiltshire alone (Glast. Lake Village, I 85 ). Somerset, Dorset, Gloucestershire, Oxfordshire, and Berkshire together dispose of another eleven, while only five come from south-east Britain. To these last must be added another from Deal, that is not included in $\mathrm{Mr}$. Gray's list. Where precisely the users of these and the late Hallstatt-early 
La Tène period pottery found in Wiltshire and the neighbouring counties came from has yet to be accurately determined, but there are some grounds for considering that it may rather have been from the south-western districts of Gaul than from the northern or central ${ }^{x}$ (Hengistbury Head Report, 33).

It has been generally accepted that there was a considerable trade in tin between this country and the Continent at a very early date, and that this commodity was probably landed in Gaul in the Garonne and Loire districts, and from there transported overland to Narbonne and Marseilles. ${ }^{2}$ This trade would have familiarized the inhabitants of western and south-western Gaul with the south and south-western portions of this island. Some of them, attracted by this pleasant and fertile country and also being pressed by the never ceasing movement from east to west in Europe, may have immigrated here and formed settlements. That there was a connexion between this part of Britain and north-west France in the later La Tène periods has been established by the similarity of some of the pottery found at Meare, Glastonbury, Wookey Hole, Hengistbury Head, The Keltic Cavern, etc., to types found in Armorica (Glast. Lake Village, 49 I, Hengistbury Head Report, 40, Arch. lxiv, 337, Proc. Spelaeological Soc., vol. i, 89). The Veneti who inhabited the Armorican peninsula and are known from Caesar to have sailed to this island, may have been descendants of people who had traded with this country from the same part of the Continent for many generations.

I The recent discoveries of Hallstatt period pottery at Scarborough made by Mr. G. Simpson, when taken into account with those from Peterborough and other isolated finds on the borders of the Fens (C. Fox, Arch. Camb. Reg., 85), as well as those at Eastbourne (Ant. Jour. ii, 354) and Park Brow near Cissbury (Ant. Jour. iv, 347), indicate that this period may be far better represented in this country than has previously been recognized. The fact that these sites are widely scattered along the coast, and that the pottery from them although having certain features in common differs considerably in many respects, suggests that the people that used it, although probably coming from a common stock in Central Europe, may have reached these shores by different routes and after periods of wandering, more or less prolonged. It is a curious fact that the fine cordoned ware of the early La Tène period found at Hengistbury Head (class B), which, although earlier, certainly belongs to the same family as the Swarling-Aylesford series and is contemporary with its prototypes in the Aisne and Marne, cannot be paralleled in those districts, nor in Belgic Gaul, neither can any record be found of its having been met with elsewhere on the Continent. The high-shouldered vessels, Hengistbury class c, which were found in association with class B do, however, occur in the Aisne and Marne, and as the prototypes of both classes are to be found immediately north and south of the Alps, there can be little doubt that the people who brought this pottery to Britain were the direct descendants of the inhabitants of that part of Europe. The fact, however, that the very distinctive vessels (class B) are not found on the Aisne or Marne or in Belgic Gaul, proves that the makers of this ware did not emanate thence.

${ }^{2}$ Diod. Sic. Bibl. Hist. v, 38 . 5 . 
In the second century в.с. the invasion of Gaul by the Cimbri and Teutones might have been the cause of emigration from that country to Britain, but the Belgic Gauls would hardly have been affected, as they were the only people that successfully defended themselves against the invaders $(B . G . \mathrm{ii}, 4) .^{x}$ In fact, it may be said that although there are indications that the area of the Belgae in this country as given by Ptolemy was in the late Hallstatt and early La Tene periods possibly inhabited by people from west and south-west Gaul, whose ancestors may have come from the district north of the Alps, there is no definite archaeological evidence of an immigration into this part of Britain from Belgic Gaul before the time of Caesar. It is possible therefore that the coming of the Belgae may be represented by the deposits of Belgic, Arretine, Mont Beuvray, and bead-rim pottery, sometimes associated with La Tène III fibulae, which have been found at such places as Oare and Casterley Camp in Wiltshire, Woodcuts Common, Rushmore, and Rotherley on the borders of Wiltshire and Dorset, Hengistbury Head in Hampshire, and other places (Hengistbury Head Report, 47). These deposits can be roughly assigned to between 50 B.C. and A.D. 50 . Some weight is given to this argument by recent excavations in Somerset, which have resulted in the theory being put forward by those who conducted them, that Glastonbury Lake Village was destroyed by a warlike people, probably the Belgae, between 50 B.c. and A. D. 50. Also that Wookey Hole and the Keltic Cavern in the Mendips were used as places of retreat when the inhabitants were driven from their settlements by the same invaders (Proc. Spelaeological Soc., vol. i, I 7-20). Much more work with the spade will, however, have to be undertaken before this can be proved with certainty. It is further obvious that if the people who, as Caesar stated, passed over from the country of the Belgae to Britain were the same as the Belgae of Ptolemy, their geographical position shows that it is unlikely that they landed in Kent ; they would probably have disembarked in west Sussex or Hampshire and passed along the high ground of the south downs to Winchester, or entered the country by some of the large estuaries on the Hampshire coast. ${ }^{2}$ In any case, as the

I See Appendix II, B.

2 Assuning, as we must, that Caesar's account is correct, the archaeological evidence seems to leave us with two alternatives: $(a)$ the Belgae reaching Britain before the invasion occupied first some area other than that in which Ptolemy places them, and only became masters of the latter during the interval between the invasions of Caesar and Claudius; or $(b)$ the tribes from the Belgic area of which Caesar speaks were not the Belgae of Ptolemy, and these crossed the Channel during one of the periods of unrest in Gaul which occurred in the course of the Triumvirate or the Principate of Augustuc. 


\section{REPORTS OF THE SOCIETY OF ANTIQUARIES}

pottery with which we are concerned is practically non-existent in this area, they cannot well be the people who brought it to this country.

The territory of the Atrebates was situated to the north-east of that of the Belgae and corresponded roughly to parts of Hampshire, Berkshire, and Surrey, their capital being Silchester, the Roman Calleva Atrebatum. There can be little doubt that they were a branch of the Belgic Atrebates who inhabited the district around Arras. Caesar does not mention them as being in this country, and they cannot be said to inhabit a maritime district. The finds from Silchester do not indicate a date for the town as early as his time, although it may be said with some certainty to have been occupied towards the end of the first century в.c., coins of Eppillus, a son of Commius, of about that period being inscribed Callev, an abbreviated form of Calleva (Evans, Ancient British Coins, 523-4). Commius himself was king of the Atrebates in Gaul, and, as already stated, was dispatched to this country by Caesar to influence the inhabitants in favour of the Roman cause. Caesar does, not say, however, that he was sending him to a section of his own tribe and Commius appears to have failed miserably in his mission, being thrown into chains as soon as he landed (B.G. iv, 27). In fact there is nothing to indicate that the Atrebates had already landed in Britain before Caesar's invasion.

Commius eventually went over to the enemies of Caesar, making himself so troublesome that on more than one occasion attempts were made to assassinate him. He escaped, but in the end surrendered on the condition that he should never again be brought face to face with a Roman. It is definitely stated that after this he came to Britain, ${ }^{\text {" }}$ possibly with a large following of the Atrebates who founded the town of Silchester, which appears to have been laid out to include a very large area from the very beginning. Sir John Evans, from the evidence of coins, believed that Commius eventually became overlord in south-east Britain to the south of the Thames, and after his death his three sons ruled respectively over the Atrebates, the Regni, and the Cantii.

Athough none of the most characteristic types of the SwarlingAylesford pottery has been found at Silchester, and therefore it is not likely to have been brought to this country by the Atrebates, the possibility that this tribe may have come to Britain after the invasions of Caesar is very important, as it suggests what has not before been put forward, that there may have been a very considerable emigration from Gaul to Britain in the century 5 O B.C.-A. D. 5 O.

\footnotetext{
I Frontinus, Strategemata, ii. 13. I I.
} 
That the Gauls chafed under the Roman yoke is known ${ }^{\mathrm{T}}$ - - there were revolts of the Bellovaci in 46 в. c. and of the Morini and Treveri in 30-29 B.c., all of whom were close neighbours of the Atrebates-and that some of them should at this time have sought freedom across the narrow straits in our country, the inhabitants of which had so successfully resisted the Roman arms, is more than probable, and may in some measure account for the fact that the great bulk of the pottery with which we are dealing should belong to a period after 50 B.c. If, however, we were to date the whole of this pottery after that date we should have to disregard entirely Caesar's statement that the maritine districts of Britain were in his time inhabited by people who had passed over from Belgic Gaul. This we can hardly do, at any rate as far as south-east Britain is concerned. The archaeological evidence, however, for any considerable movement of people into this district in the early Iron Age, apart from the AylesfordSwarling series of finds, is small in the extreme. At Broadstairs and Margate there are somefragments of pottery as yet unpublished of the Aisne and Marne types, which are certainly earlier than La Tène III. The remains of two or three Hallstatt period pots, apparently made in this country, were found at Eastbourne (Ant. Journ. ii, p. 354), two others of about the same period from Deal are in the British Museum (Proc. Soc. Ant. xxvi, I 29), while recent excavations at Park Brow near Cissbury (Ant. Jour. iv, 347) show that a Hallstatt period settlement existed there. Of the five La Tène I fibulae found in south-east Britain and listed by Mr. St. G. Gray (Glastonbury Lake Village, I 85), four were found in the Thames and one at Lancing. To these must be added another from Deal, now in the Deal Museum. The only two La Tene II fibulae from this district were found in London, and there is one transitional specimen of La Tène II or III from Walmer, Kent (Glastonbury Lake Village, 190; British Museum, Early Iron Age Guide, roo), and another in the British Museum from the Warren, Folkestone.

These scanty finds, which all come from the coast or out of the bed of the Thames or from its banks, may represent the first arrivals of the early Iron Age people or indicate trading stations, but they do not supply sufficient evidence to suggest any considerable immigration or an invasion. Trade may also account for the earliest debased copies of coins of Philip of Macedon and others of the same period found in this country which have been used as evidence for a Belgic invasion about i 50 or even 200 в. c. This theory was based on Sir John Evans's conclusions that these coins

$$
\text { I See Appendix II. }
$$


were made in this country at about that date. Since his book was published, opinion as to the provenance of the earliest types has altered; Mr. G. F. Hill, Keeper of Coins and Medals at the British Museum, has supplied me with much information on the subject, and there is little doubt that certain categories which have in the past been ascribed to Britain are not British at all. For example, those illustrated on pl. A, nos. I-8 of Sir John Evans's book are found in greater numbers in Gaul and are attributed to the Bellovaci by French writers (Blanchet, Tr. des Monn. Gaul. 369). Similarly the resemblance of the coins illustrated in pl. B, $1-6$ and $8, \mathrm{D}, 2-4$ to coins of the Atrebates and Morini respectively is so close that it cannot be said which, if any, were made in Britain (Blanchet, Tr. des Monn. Gaul. 342, 346, 349).

The earliest British inscribed coins appear to be those of Commius (Evans, pl. I, IO; 82, $83 \frac{1}{2}$ grs.) and can hardly be earlier than the middle of the first century B.c. Some of the coins of his son Tincommius (Evans, pl. I, I I, I $2 ; 83 \frac{1}{2}$ grs.), who was almost certainly a contemporary of Augustus, are very similar in type to those of Commius, and the whole of this group differs very little from certain uninscribed varieties (Evans, pl. D, $5 ; 82 \mathrm{grs}$.) which should therefore not be far removed in date. These last are again very like certain heavier coins (Evans, pl. в, $9 ; 90$ grs.), which it is hard to believe can be separated from them by any considerable space of time in spite of their greater weight. It is also certain that to place this series of coins in chronological order based on degradations of type or fall in weight is distinctly dangerous, as these two factors do not by any means always go together. For instance, Evans B, I-6, weighing $93 \frac{1}{4}, 90,95 \frac{1}{10}, 96 \frac{1}{4}, 95$, and $96 \frac{1}{4}$ grs. respectively are of a more debased character than the inscribed coins of Commius and Tincommius ( $82,83 \frac{1}{2}$ grs.) mentioned above. In connexion with this it should be borne in mind that these coins were probably minted in a number of places at the same time, and there is no certainty that the same quality of metal or the same standard of weight were used at each mint. Also the devices on the coins must have been affected to an appreciable degree by the individual skill of the workmen.

The length of time some of these coins may have been in circulation is also very uncertain, but that it may have been considerable is shown by the fact that two gold coins (Evans, pl. B, 5, and pl. c, 9;92.3 and 83.6 grs.) were found in association with coins as late as the middle of the second century A.D. at Hengistbury Head (Hengisibury Head Report, 67). A lengthy circulation may well account for the wide distribution of some of the types. The Hengistbury find, just referred to, also proved that very rough 
copies of the British coins were still being minted in the second century A.D.

If, therefore, we eliminate as being Gaulish the earliest coins found in this country, there is no reason to believe that any coins were struck in Britain before 100 B.c., and it is very possible that the earliest examples may even be several decades later.

It will be seen, therefore, that the coin evidence coincides very closely with what is believed to be the date of the introduction into Britain of the pottery under discussion. It is true that there are imported La Tène coins and bronzes of an earlier date in Britain, but these, where not found with contemporary pottery from the same foreign source, can hardly be used as evidence of an invasion; they are much more likely to have been brought to this country by trade. Pottery, on the other hand, especially if found in any quantity with burials, and practically all belonging to a particular class, can only represent an occupation by the people who made and used it.

It has been proved highly unlikely that either the Belgae or Atrebates were responsible for bringing the Swarling-Aylesford types into Britain. Of the other two Gaulish tribes known to have been in this island the Parisii inhabited the vicinity of the Humber, and it has been suggested that the burials with chariots, such as those at Arras in Yorkshire, are connected with these people. This custom also existed in Gaul, but at a considerably earlier date than the period with which we are dealing, and although it is therefore possible that this tribe arrived in Britain well before Caesar's time, the fact that none of the pottery under discussion has been found in their area proves that it cannot have been brought to this country by them.

This then leaves only the Catuvellauni, whose chief towns according to Ptolemy were Urolamium, obviously Verulamium (St. Albans), and Salinae, a site which cannot now be identified, though it is thought to have been Sandy in Bedfordshire. Although Caesar does not mention them, he states that the chief command of the British forces was entrusted to Cassivellaunus, whose territory was north of the Thames and about eighty miles from the sea to the west of the Trinobantes (the inhabitants of Essex and part of Middlesex) (B.G.v, I I).

At the time of the Claudian invasion, A.D. 43, Caratacus and Togodumnus are stated by Dion Cassius $(B .60$, cap. 20$)$ to have been Catuvellaunians. Their father and grandfather Cunobelinus and Tasciovanus must therefore also have been Catuvellaunians. From the distribution of coins (Evans, Ancient British Coins, p. 225) and chronological considerations, it seems reasonably certain that 
Tasciovanus ruled over an area including that of Cassivellaunus, a generation after the latter, and was, therefore, his successor and presumably his son. Thus it is rendered highly probable, though not certain as is often stated, that Cassivellaunus was king of the Catuvellauni, or at any rate overlord of a confederacy of tribes of which the Catuvellauni were one.

Now it has been generally accepted that these people were the same as the Catalauni or Catuvellauni of Belgic Gaul, one of whose towns was the modern Châlons-sur-Marne, and who were therefore situated in an area very prolific in the prototypes of the Swarling-Aylesford pottery (Déchelette, Manuel, p. I060, pl. III).

There is also a direct historical reference indicating a close connexion between this district of Gaul and Britain, as the ambassadors of the Remi are reported by Caesar to have stated that Divitiacus, the most powerful man of all Gaul, had been king of the Suessiones (the next tribe west of the Catalauni in Gaul), and that he had held the government of a great part of those regions as well as of Britain $(B . G$. ii, 4$)$. That he should have had this authority in Britain can only be explained if tribes, or sections of tribes, over which he ruled in Gaul had succeeded in invading and settling in this country. Another Divitiacus, the Aeduan Druid, gave a very good reason for a movement of tribes westwards and northwards from eastern and central Gaul at about this period, when he explained the conditions in that country to Caesar. He told him of the struggles for supremacy between the two main parties, the Aedui at the head of one and the Arverni of the other, and how the Arverni and the Sequani had called in the Germans to help them, and with their assistance had defeated the Aedui. The conquerors were not, however, allowed to reap the fruits of their victory in peace, as the Germans--there were 120,000 of them in Gaul-having become enamoured of the land, refused to return to their own country. They seized upon a third of the territories of the Sequani and demanded the evacuation of another third to make room for 24,000 more of their followers. Divitiacus believed that in a few years the Gauls would all be driven from their territories, and that unless aid was given them by the Roman people, they would be forced, as the Helvetii had been before them, to emigrate from their country and seek settlements elsewhere remote from the invading German $(B . G . \mathrm{i}, 3 \mathrm{I})$.

It can be said, therefore, that there is a very strong presumption that part of the Catuvellauni, and possibly other tribes from the same district, may have moved to this country a little before or about the time of Caesar. That the tribes in Kent were already under the sway of Cassivellaunus at this period is shown by the 
fact that they accepted him as commander-in-chief against Caesar. Even after the Romans had penetrated north of the Thames, the Kentish chiefs carried out his orders to attack the camp defending Caesar's naval base (B. G. v, 22). How far Cassivellaunus had succeeded in bringing the country north of the Thames under his rule cannot be determined, but it is known that just before Caesar's invasion he was waging war against the Trinobantes, had killed their king Imanuentius and forced his son Mandubratius to flee to Caesar in Gaul for protection (B. G. vl, 20). His defeat by Caesar did not long curb his lust for conquest, and the territory of his successor Tasciovanus is believed by Evans from the evidence of coins to have stretched as far north as Northamptonshire, and possibly included the whole area of the Trinobantes. In any case these people were under the rule of his son Cunobelinus, some of whose coins bear the name of Camulodunum (Colchester). This prince is believed to have begun to reign about A.D. 5 (Evans, Ancient British Coins, pp. 222-9), and the whole of south-east Britain appears to have been under his supremacy (Evans, op. cit., p. 287). Suetonius even gives him the title of Britannorum Rex (Caligula, 44).

It will be seen how closely this history of the Cassivellaunian dynasty coincides with the appearance and distribution of the Swarling-Aylesford types of pottery. The earliest pottery is in Kent, where the invaders would have first landed and established settlements. The finding of early examples on the south-east coast of Essex, such as the fine pedestal urn at Shoebury, may indicate that a landing was also made on the north bank of the Thames. It would seem, however, that at first it was found impossible to overcome the resistance of the Trinobantes, and the advance was continued up the Thames, Cassivellaunus establishing himself to the north of it some 80 miles from the sea, where we find him at the time of Caesar's invasion. From here either he or his descendants attacked and defeated the Trinobantes, establishing settlements over their country and even as far north as Northamptonshire and Huntingdonshire, where pottery late in the series is met with. These people, the descendants of the inhabitants of the Aisne and Marne, continued to make their pottery in the style of their ancestors until, or even a little later than, the Claudian invasion in A. D. 43, when their art was submerged by the overwhelming Roman influence. The coming of these people may well have been the first definite invasion of south-east Britain from Belgic Gaul, and if so would account for the Atrebates and the Belgae, if they arrived later, landing beyond the forest of Anderida and having to seek new territory further to the west. 


\section{APPENDIX I \\ Report on the Brooches, etc. \\ PLATES XII-XV

\author{
By Reginald A. Smith, F.S.A.
}

No. I (Swarling; Grave Group 4). Iron brooch of La Tène IIl type, much rusted and broken : either exceptionally long, or parts of a pair. Double bilateral spring, with inferior chord (passing under the head). The form of the foot cannot be determined, but the head resembles one figured in Pitt-Rivers, vol. ii, pl. CI, fig. 6, from Rotherley (foot missing), and another of bronze with solid catch-plate from Woodcuts (op. cit., vol. i, pl. XI, fig. 2). One of much-rusted iron from Danes Graves, E. R. Yorks., has an open foot reversed in the early manner of La Tène (Arch. 1x, 268, fig. (5), but in no case is the angle of the bow so pronounced.

No. 2 (Swarling; Grave Group I 7). Pair of bronze brooches, much corroded and broken : originally $2.8 \mathrm{in}$. long, with triple bilateral spring and straight bow with central rib (roof-like) and marginal lines, the catch-plate with step-pattern in open work. This pattern resembles, but is probably earlier than, that figured from Pommiers, Aisne (Déchelette, Manuel, ii, 967 , fig. 403, no. I), which has a hook to hold the chord, and a more tapering bow. It is referred to La Tène III, dating before $5 \mathrm{I}$ B.c. (ibid., p. 968). There is some resemblance also to one from Mont Beuvray (the ancient Bibracte, in Saône-et-Loire), figured by Bulliot (Fouilles $d u$ Mont Beuvray, Album, pl. L, no. 6), and a date is supplied by the abandonment of the site during the reign of Augustus (B.c. 27A.D. I4), the coins ceasing about B.C. 5. The Swarling type may be the predecessor of two from France figured by Oscar Almgren in Opuscula Oscari Montelio, p. 244, fig. 8, and p. 246, fig. I I, both ot which apparently have a cylindrical cover to the spring, which (according to Déchelette, Fouilles du Mont Beuvray, p. I 40) was evolved from the wings seen on some of the Swarling specimens. A more elaborate example with cylindrical cover found at Andernach (Bonner Jahrbilcher, 86, fig. 25, see p. 220) is assigned to the reign of Tiberius (A.D. 14-37), and fig. 12 of the same series, much closer to our fig. 2, is evidently earlier. 
No. 3 (Swarling; Grave Group 13). Pair of stout bronze brooches, harp-shaped, imperfect especially at the foot, which was evidently open : double bilateral spring with inferior chord, covered by the trumpet-shaped expansion of the head. The bow is of circular section with mouldings passing all round the angle (not flat inside). This type is evidently derived from La Tene II, the moulding on the bow representing the collar that once attached the returned end of the foot to the bow. It is very like the pair found in the Aylesford cemetery (Arch. lii, 38I), details of which are reproduced in the British Museum Early Iron Age Guide ( 1905 ), fig. 96 ; but unfortunately the foot is missing in all these cases, and even the traces of any hook beside the moulding towards the foot are not quite clear on the Swarling specimens. As Sir Arthur Evans intimated in 1889 , the Aylesford brooches may hail from Italy, as they were found in the bronze-plated bucket which accompanied the bronze jug and patella, evidently of Italian fabric. There is further a parallel from Perugia (Almgren, Nordeuropaische Fibelformen, pl. IV, fig. 65 ; Montelius, La Civilisation primitive en Italie, i, pl. XII, fig. I 73), and something similar from Ornavasso (Atti della Società di Archeologia e Belle Arti, Torino, vi, pl. X). Tischler illustrated one from Gurina in the Obergailthal, Carinthia (Gurina, p. 25, pl. VI, no. 5), with open foot like our specimen, and dates them before the Roman Empire, the open or open-work foot being characteristic of the last century B.c. R. Beltz assigns this type to $\mathrm{La}$ Tene $11 \mathrm{l}$ in a comprehensive paper on $\mathrm{La}$ Tène brooches in Zeitschrift für Ethnologie, xliii ( I 91 I), p. 689, fig. 59, but he illustrates no other paraliel to the Swarling series, maintaining with Tischler that the hooked chord is a sign of Roman date (on the Continent).

No. 4 (Swarling; Grave Group I.) Bronze brooch, almost complete, collected by Dr. A. G. Ince and found in one of the two Swarling urns which he has presented to the British Museum. The bow tapers to the foot, which is open and may have had steppattern within : the head is a right angle and expands laterally over a quadruple bilateral spring, the chord of which is superior (outside) and is held to the head by a hook. L. 2.I in.

This closely resembles one from Woodcuts Romano-British village illustrated by Pitt-Rivers, vol. i, pl. XIII, no. I I, but the foot of this is unfortunately missing: it was probably solid, like most of the early brooches from that site. The type looks earlier than Hofheim, ${ }^{1}$ Album, pl. VIII, no. 8 r or text, p. I37, no. 10,

I Annalen des Vereins für Nassauische Altertumskunde und Gescbichtsforschung, xl (IgI 2): Das frübrömische Lager bei Hofbeim im Taunus, von E. Ritterling. 
for which a date is provided (about A.D. 4O, as the type evidently belongs to the beginning of the occupation). Also to judge by the foot, Dr. Ince's brooch is earlier than Novaesium (Neuss), pl. XXIV, nos. I 3-I 8, of the album (text in Bonner Jahrbücher, I I 2, 390), and the occupation at Neuss began about A.D. 4I. Ritterling (op. cit., p. I 34) says this type is poorly represented by eleven specimens at Hof heim, whereas at Neuss (whose early period coincides with $\mathrm{Hofheim}$ ) there are thirty-four specimens; but he considers this a local rather than a temporal difference, as the type preferred the lower Rhine and lower Moselle, where it replaced Almgren's no. 20, which is well represented on the middle Rhine.

The Kelvedon brooch referred to below (no. I 3, p. 44) is half as long again as Dr. Ince's specimen, but evidently of the same type ; and it shows how the foot was originally filled with open work. There are no wings at the head to protect the spiral spring, which in this case consists of six coils (not eight, as in no. 4).

No. 5 (Swarling; Grave Group 19). Head and part of pin of a bronze brooch with flat bow broadest at the head, and quadruple bilateral spring with superior (outside) chord held by a hook which is attached to the head with an engraved circular terminal. The foot is entirely missing; but to judge from the head, this specimen should be about contemporary with the last, and earlier than the following. No close parallel has yet come to light.

No. 6 (Swarling ; Grave Group I 9). Bronze brooch with arched bow, complete except for half the spring, the pin and catch-plate. Originally with quadruple bilateral spring, the chord being superior (outside) and caught up by a hook on the head : the bow with slight marginal lines from end to end, and the catch-plate apparently solid, and so restored in the illustration. L. I. 4 in.

This is apparently the latest of the series, the lateral extension of the head over the spring being grooved to imitate coiled wire, and the hook being much exaggerated. The form of the bow also presents a contrast to the rest, which are low and nearly straight; and the solid catch-plate suggests a later date than the others. It is possibly the predecessor of the Aucissa brooch, which is well represented at Hofheim, and a specimen from that site, with simpler head, will serve as a parallel to what is probably the latest brooch at Swarling. It should belong to the very beginning of the Hofheim period (say A.D. 40) as the Aucissa brooch is held to have begun with the Christian era (Arch. Jour. 1x, 242). The 
hinge then made its first appearance, but the earlier coiled spring did not at once go out of use.

With this was the lower half of the bow of a small brooch resembling the imperfect specimen found with the Trelan Bahow mirror, St. Keverne, Cornwall : both are illustrated in Archaeologia, lxi, 330. But in neither case does the brooch give any precise indication of date or origin.

No. 7. An interesting parallel from a burial at Deal, and now in the local museum. Only the pin is missing, and the bow and foot are almost identical with no. 2 , but the head differs in having wings to protect the spiral spring, and there is a bold catch for the chord, fastened to the head much like no. 5 . L. 3.5 in.

No. 8. This was found in the same burial as the last, and is therefore contemporary, though the open-work catch-plate is of a simple pattern. The bow tapers to the foot and has a pronounced angle in the head like no. 4 , both having wings to protect the spring. This Deal brooch shows the style of open work now missing in no. 4 .

No. 9. An exceptional specimen of the type evidently dominant at the time the Swarling cemetery was in use : it came like nos. 7 and 8 from Deal, 15 miles to the east. In perfect condition, it has a tapering bow like no. 8 , but both it and the wings on the spring are more elaborate, and the open-work catch-plate almost rivals the best specimens from N. Italy. From the absence of any collar or other trace of La Tène II style, this is no doubt later than the specimens found in a grave with Roman coins of 88 and 84 B.c. at Persona, Ornavasso in the Ticino valley (Atti della Societic di Archeologia e Belle Arti, Torino, vol. vi, p. 227, pl. X).

A simpler example from a burial near Shorne, Kent, is illustrated in C. Roach Smith's Richborough, Reculver, and Lymne, 8I, fig. 2 ; and the type can therefore be regarded as the commonest at the period indicated by the pottery.

No. IO. A Folkestone specimen of the same type as the preceding but with damaged catch-plate, and the bow more arched than in no. 4. Small wings to protect the opening, and a catch to secure the chord to the head. L. $2.6 \mathrm{in}$.

No. I I. The only one of its kind found, probably the predecessor of a group found at Hod Hill, Dorset, which is assigned to about A.D. 50. The transverse ribbing of the bow is certainly advanced, and does not seem to have sprung locally from any known variety; but is evidently related to continental specimens. L. about $1 \cdot 2$ in. from Folkestone, found with no. 12 . By the 


\section{REPORTS OF THE SOCIETY OF ANTIQUARIES}

Flavian period a hinge had replaced the bilateral spring (Neuss, Bonner Jahrbücher, i I 2, 392, pl. XXIV, 29 etc.); but no. I I should date before the Claudian Conquest, as the Hod Hill specimens are hinged.

No. I2. A fragile specimen on the lines of the principal type already described, but with rudimentary wings over the spring, and no catch for the chord; hence probably earlier than no. 10, for instance. Not only the structure but the size may also be an indication of relative date in these cases. From Folkestone, found with no. I I. L. about I.5 in.

No. I 3. The urn with which this brooch was found at Kelvedon, Essex, has been mentioned above (p. 22). The usual features can be recognized, the angular bow, open-work catch-plate, spiral spring with external or superior chord caught up by a hook. It lacks wings on the spiral spring, but otherwise is clearly related to nos. 4 and ro. L. 3 in. Though published in 1870 (Proc. Soc. Ant. $v, 30$ ) this brooch has never been illustrated, and is as useful here as the bowl in illustrating the Swarling series.

No. I 4. Brooch of the same general character as those already described, but with the bow more arched and presumably later, as the harp-shaped brooch is characteristic of the early second century of our era. It is very like no. 10: the chord is attached to the head by a loop, the bow tapers towards the foot, and the catch-plate is perforated; but typologically this is earlier than the specimen associated with Early British bridle-bits and other bronzes at Polden Hill, Somerset (Early Iron Age Guide, Brit. Mus., 1 905, fig. 109), as the latter has a half-cylinder to protect the spiral spring. Found at Allington, Kent (Maidstone Museum). L. $2 \cdot 9$ in.

No. 15. Very like the last, but shorter, the catch-plate originally ornamented with open work, but now incomplete. Found with cinerary urn at Hermitage Farm, Allington, Kent, 1923 (Maidstone Museum). L. 2 in.

No. I6. Five brooches from an Early British cemetery at Deal, but with which, if any, of the pottery vessels in the collection they were found associated is not recorded. They all mark an intermediate stage between the Ticino specimens referred to under no. 9, and three others from Deal (nos. 7-9); and show that the collar (or attachment of the returned foot to the bow) ceased to be functional and, after becoming merely ornamental, was eventually omitted altogether. L. of largest, $4 \cdot I$ in. (Deal Museum). 
No. I 7 ; pl.XIV. A slender bronze loop with open-work lozenge below, probably for attachment to the lip of a small wooden bucket with arched drop-handle. The loop shows signs of wear within, and the open-work plate is imperfect but restored in the illustration, the length being $I \cdot 9$ in. obtained by Dr. A. G. Ince from one of the burials at Swarling and since presented to the British Museum. Some support for the above interpretation is found in the smaller bucket or bronze-plated tankard at Aylesford; but there seems to be no exact parallel for the bronze, even at Stradonitz in Bohemia, where small bronze mounts are abundant. The same technique is, however, found in the famous chariotburial at Somme Bionne (Brit. Mus., Early Iron Age Guide, Ist ed. pl. III, left), which probably dates from late in the fifth century B.c.; and there is nothing in the style of this escutcheon to suggest that it is not contemporary with the other Swarling burials.

Some attempt at a chronological arrangement of the above specimens must be made, but as most if not all of them were manufactured abroad and may have been imported from different areas, the line of descent cannot be regarded as continuous. The earliest should be nos. I, 3, and 16, about 50 B.c.; these are followed by the main period at Swarling, with its more elaborate specimens, the order being possibly nos. $4,9,8,2,7,5$, and the range of date between 25 B.c. and A.D. 25 in round figures. There must be an interval between the stages of evolution marked by nos. I 6 and 13 , as the collar on the bow has vanished, and the chronological order of the late group may be nos. I $3,12,10,15$, I 4, 6, and I I, possibly all dating between A. D. 25 and 50. This order is not in complete agreement with the grave-groups, but it will be readily admitted that brooches a generation apart in date may be found in the same burial. The fashion of wearing oldfashioned brooches is by no means extinct in our own time.

The brooches do not fix the date of Swarling within definite limits, and at present only indirect methods are available : but valuable negative evidence may be derived from the absence of types that have a recognized chronology. The Aucissa type is not the only one at Hofheim that is conspicuously absent from Swarling, but yet represented in other parts of England: the 'eye-brooch' (Augenfibel) is another case, and it is important to observe that a variety of this was found with the famous Birdlip mirror now in Gloucester Museum (Archaeologia, lxi, 341). Sites roughly contemporary with Swarling, such as Hunsbury (Arch. Jour. lxix, 427), Glastonbury, Mont Beuvray (abandoned about 5 B. c.) and Haltern, are of little service here; and even 


\section{6 - REPORTS OF THE SOCIETY OF ANTIQUARIES}

Alesia (Alise-Ste.-Reine, abandoned 52 в. c.) does not clinch the argument. Some of the specimens there are discussed by Oscar Almgren in Opuscula Oscari Montelio, 24I, figs. I-6, but others are figured in Pro Alesia (Oct. 1907, pl. XXXII) that certainly date after the Christian era, and the value of the site as a chronological fixed point is thereby impaired. Even those illustrated by Almgren may not all be before 52 в.c.

It may be said with some confidence that no brooch dealt with in this paper is before $75-100$ B. C., while the latest may come down to the Roman period in Britain.

\section{APPENDIX II}

By Donald Atkinson, M.A.

\section{A. Campaigns, Revolts, and unrest in Gaul after the withdrawal of Caesar}

I. 46 в.c. Livy, Epit. I I 4. 'Brutus the lieutenant of Caesar conquered in a battle the revolting Bellovaci.'

2. 44-3 в.c. Campaign of L. Munatius Plancus against the Raeti on the borders of Gaul (i.e. in connexion with the foundation of the colony of Rauraca (Basel-Augst)), known from the Fasti Triumphales which record the triumph of Plancus. Many references in Cicero's letters at this time (44-2) to the state of peace in Gaul (e.g. Ad Att. xiv, 9, 3 'omnia plena pacis').

3. Appian, de Bell. Civ. v, 75. After this (i.e. in 39) Caesar (i. e. Augustus) made an expedition into Gaul which was disturbed (presumably by revolts among the Aquitani).

39-8 в.c. Campaigns against the Aquitani by Agrippa, Appian $v, 92$, 'And at the same time a glorious victory was an nounced over the Aquitani won by the leadership of Agrippa': Eutropius vii, 5 mentions merely conquest of Aquitania in the time of Augustus : Dio xlviii, 49. 2. 'He himself (i. e. Augustus) looking after .... the affairs in Italy and in Gaul (for a rising took place among them) . . . . . for Agrippa was making war on those of them who had revolted, when second of the Romans he crossed the Rhine on a military expedition.....' This shows that the trouble was not confined to the S.W. in these years.

4. 30-29 B. c. Campaign of Carrinas against the Morini and of Nonius against the Treveri, Dio li, 20. 5 'For the Treveri inciting 
the Gauls (to revolt) were still under arms ....... and they were defeated by Nonius Gallus.' li, 2 I. 6, 'For Gaius Carrinas defeated the Morini and certain others who had revolted with them.'

5. 29-28 в.с. Campaign of Messala against the Aquitani, Appian iv, 38. 'And afterwards Messala, being sent against the revolting Gauls, won a triumph'. There are also references to the campaign in Tibullus, whom Messala took with him to write poems on his victories, but except that it was against the Aquitani his verses contain no details. Tibullus i, 7, I-I2: ii, I, 33; cf. Jullian, Hist. de la Gaule, iv, 64, n. 9.

6. 27 B.c. Dio liii, 22. 5. 'Augustus set out with a view to an expedition against Britain, but coming into Gaul he remained there: for the Britons thought well to enter into negotiations with him, and the affairs of the Gauls were in disorder, for naturally after their recent subjection internecine wars were still continuing.'

7. I9 в.c. Dio liv, I I. r. 'Agrippa ...... was appointed to the (provinces of) Gaul. For the Gauls were quarrelling among themselves and were being harried by the Germans.'

8. I6-I 5 B.c. Dioliv, 2I. Unrest caused by the exactions of the procurator Licinus.

9. I 2 в.c. Dio liv, 32. I. Unrest on the occasion of the taking of the census by Drusus, etc.

\section{B. Invasion of the Cimbri and Teutones}

The details of the movements of these in Gaul are scanty and unsatisfactory.

The Cimbri came down from the north-east and are first heard of in I 3 B.c. in Noricum, where they defeated near Noreia a Roman army under Carbo (Livy, Epit. 63; Strabo v, 214; Appian, Celt. I 3, who, apparently wrongly, calls them Teutones). After this, in company with the Teutones, who are now first mentioned, they moved into Gaul, apparently through Raetia north of the Alps (Vell. Pat. ii, 8 'The Cimbri and Teutones crossed the Rhine'; Appian, 1.c. 'The Teutones proceeded to Gaul'). Both peoples then disappear until I $\circ$ B. c., when they are found near the Italian frontier, defeat the Romans under the consul Silanus, and demand land (presumably in Gallia Narbonensis) on which to settle, but the Senate refuses their request (Livy, Epit. 65). About the same time some of the Helvetii also entered Gaul, and a section of them, the Tigurini, defeated Longinus in 107 in the territory of the Allobroges (the east side 


\section{REPORTS OF THE SOCIETY OF ANTIQUARIES}

of the Rhone valley) or, according to an emendation made by Mommsen, in the land of the Nitiobroges (south-east of Bordeaux) (Caesar, B. G. i, 7, 1 2, 30 ; Livy, Epit. 65). In 105 в. c. the Cimbri prepared to invade Italy and defeated Scaurus, and later the consuls Maximus and Caepio at Arausio (Livy, Epit. 67). But after the battle the Teutones remained in Gaul-if indeed they had taken part in these operations at all, which is doubtful. Besides Appian, who certainly in more than one passage says Teutones when he should say Cimbri, only Velleius has mentioned the Teutones at all up to this point, so that the earlier movements of the latter are quite uncertain. In spite of their success the Cimbri abstained from attacking Italy and proceeded to Spain, but the resistance of the natives rendered their expedition abortive (Livy, Epit. 67). They returned to Gaul in 103 and combined with the Teutones (who were at all events in Gaul by this time) in the district of the Veliocassi (round about Rouen), (if we accept the emendation by Mommsen of Livy, Epit. 67, where the manuscript said reversique in Galliam bellicosis se Teutonis coniunxerunt (Cimbri), but the latest text of Livy (Teubner, 1914) accepts the conjecture 'in Veliocassis '). It may be observed that if this conjecture is right the invaders are found in a region not very remote from that in which the prototypes of the pottery under discussion have come to light. They then proceeded so to ravage the whole of Gaul as to leave a vivid remembrance of their presence half a century later (Caesar, B. G. i, 33), 'lest when (A riovistus and his Germans) had occupied the whole of Gaul as the Cimbri and Teutones had done before, they should proceed against the province of Gallia Narbonensis) ...'; B. G. vii, 77 (speech of a chief of the Arverni): "What then is my advice? To do what our ancestors did in the war with the Cimbri and Teutones, which was less serious than the present war ; when they were pent up in fortified towns and reduced to the same straits as we are, they kept body and soul together on the bodies of those who by reason of age seemed useless for military purposes, and so avoided yielding to the enemy ... When Gaul had been devastated, and a great calamity had befallen it, the Cimbri left our territories and went off to other lands.'

We learn further that the Belgae alone succeeded in keeping the invaders away. Caesar, B. G. ii, 4 , says '(The Belgae) were the only ones within the memory of our fathers who when all Gaul was harassed by the Cimbri and Teutones prevented them from entering their territories'. 


\section{APPENDIX III \\ The Iron-smelting Works \\ By C. Leonard Woolley, M.A.}

In the larger island site, the S.W. projection was surface-skinned and produced nothing at all. The S.E. corner of the site was more interesting. The face left by the gravel-workers showed a

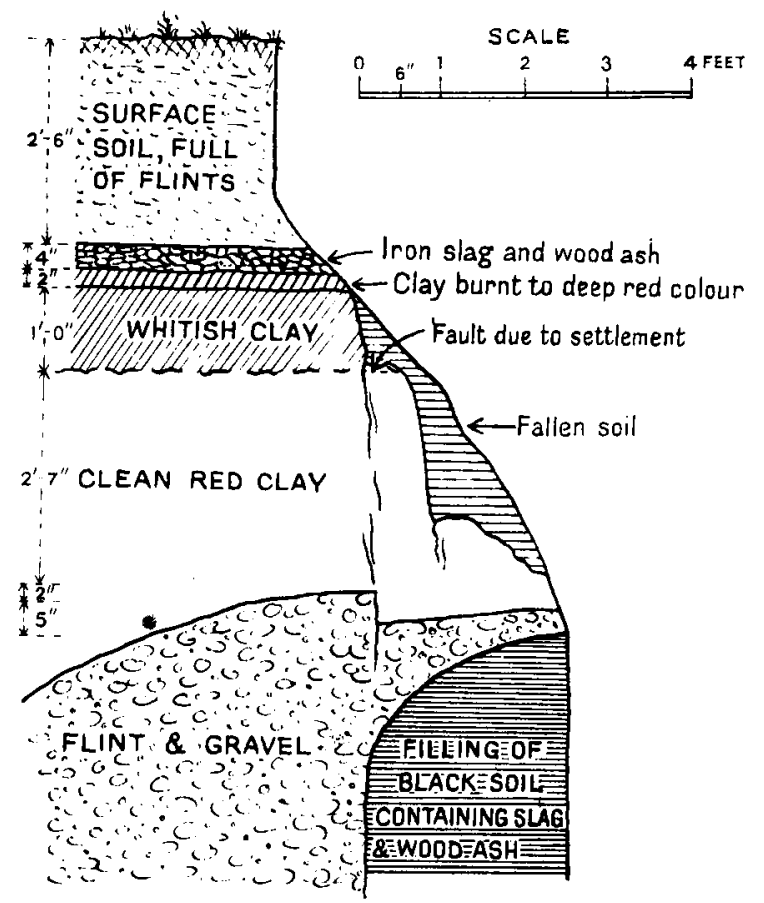

FII. 2. Section of gravel face showing iron-smelting works.

remarkable stratification. At $2 \mathrm{ft} .6 \mathrm{in}$. below the modern surface was a layer of iron slag and wood ash resting on a thick bed of whitish clay of which the top two or three inches had been burnt to a deep red colour : below the whitish clay was a bed of clean red clay $2 \mathrm{ft} .7$ in. thick at the east end and running deeper towards the west, which rested on flint and gravel. Just at the corner of the island this flint and gravel had been deeply undercut, the exposed face showing half of a bottle-shaped excavation filled 


\section{REPORTS OF THE SOCIETY OF ANTIQUARIES}

up with black soil mixed with wood ash and fragments of iron slag (see fig. 2).

The top soil was cleared, laying bare the iron-slag stratum, which did not reach far inland, most of it, obviously, having been destroyed in the course of the gravel-working. The south-east corner of the pit was cleared out and cut back so as to get a fresh
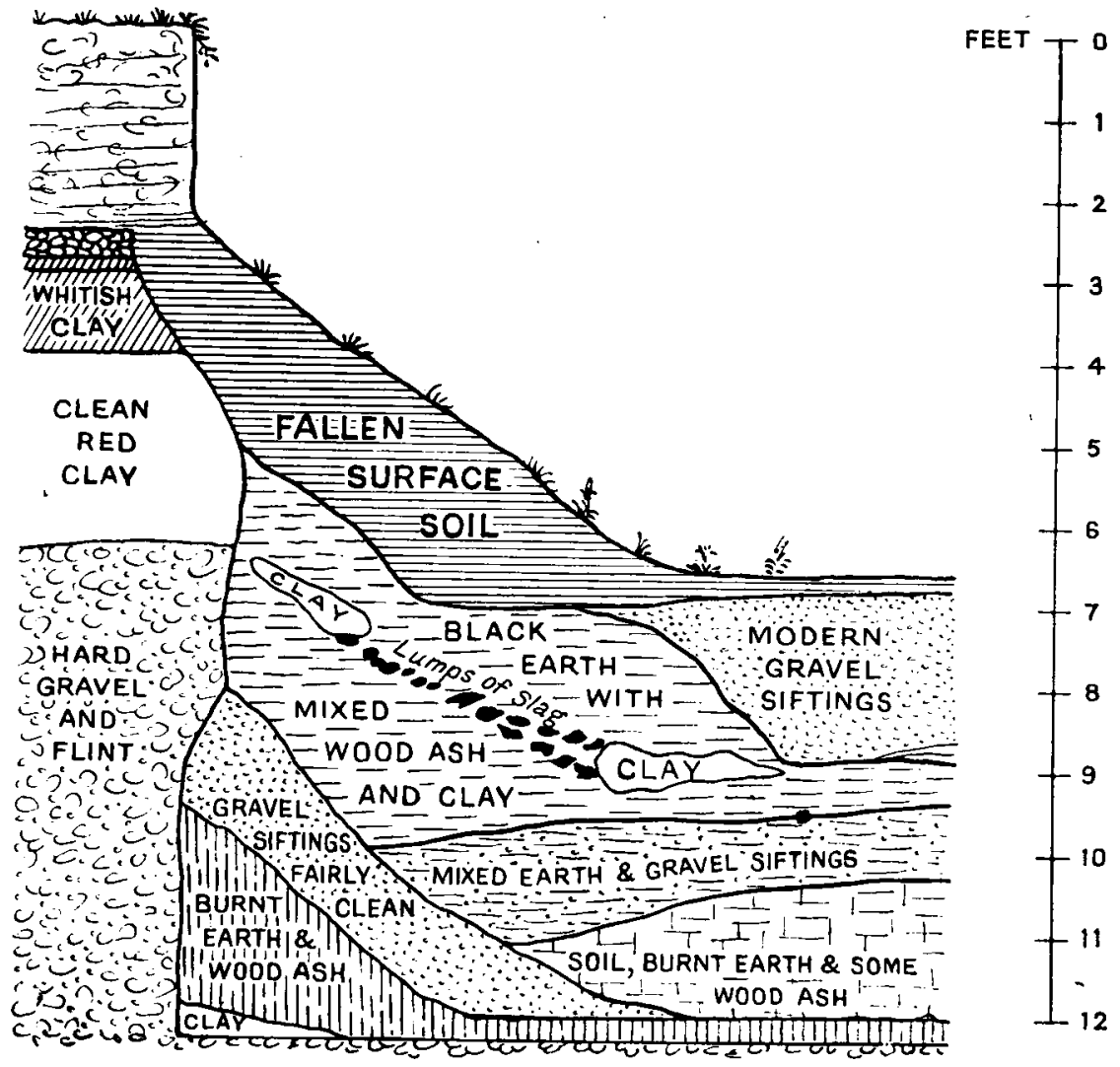

FIG. 3. Section of gravel face at iron-smelting works.

section, which taking the untouched gravel as the centre of an imaginary circle lies along a radius at an angle of about $45^{\circ}$ with fig. 2. Here the undercutting was less marked. The pit (whose limits eastwards were not found) was clearly much longer than it was wide : it ran east by west, the sides were scooped out into the gravel, and the ends, or at least the west end, nearly vertical: the bottom was quite flat, the sides below the level visible in fig. 2 sloped sharply inwards and the slope cut in the gravel was lightly faced with clay, though whether this was due to exposure 
and water-action or to artificial puddling was difficult to say, but some signs of burning on the clay made the latter rather more probable.

In fig. 3 , the two lowest strata in the pit, that of burnt earth and wood ash, and that of fairly clean gravel siftings, have certainly been tipped (not thrown) into the pit from the platform above : the strata to the right, that of soil, burnt earth and wood ash, and that of mixed earth and gravel siftings, have either been thrown from the platform or thrown in from the other end of the pit; these are all ancient deposit. The heavy mass of black earth with mixed wood ash and clay and the slant line of slag lumps is due

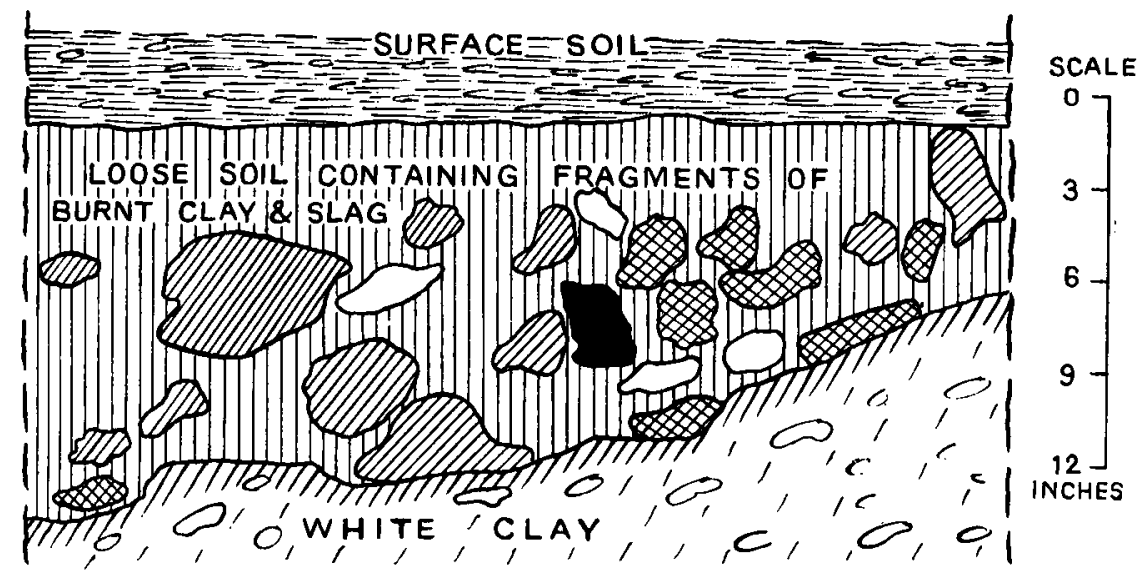

$$
\begin{gathered}
\square=\text { rusted iron } \quad \text { iron slag } \quad \square=\text { burnt clay } \\
\square=\text { flint - only larger fragments drawn } \\
\text { FIG. 4. Section across foundry floor. }
\end{gathered}
$$

to the collapse of the platform edge and represents the period of disuse : it had been cut into by modern gravel-workers who, finding no flint, had abandoned the site and filled up with gravel siftings the hole which they had made.

Figs. 4 and 5 show cross-sections of the slag and burnt clay strata of the platform. Only the larger lumps were actually drawn, and the result of this is perhaps rather misleading as it gives to the strata a more mixed appearance than they really possessed when the innumerable small fragments were visible. Agricultural work (the ground has been under grain crops and under hops, and the latter mean deep trenching) has disturbed the stratification, but the general effect is one of slag predominating above, rusted lumps of fairly pure iron below, but in less quantity, and a well- 


\section{REPORTS OF THE SOCIETY OF ANTIQUARIES}

defined layer of burnt clay lying on the white : much charcoal occurs in the two upper strata.

There is no doubt that we have to do with iron-smelting works, and fragments of Late Celtic pottery found low down in the pit and on the burnt floor of the platform suffice to fix its date; the difficulty is to determine the process employed. The thorough discoloration of the upper surface of the clay bed showed that firing had taken place on the platform itself, and the quantity of charcoal lying above it confirmed though it did not prove this. The large size of some of the thin cakes of slag implied that the ore

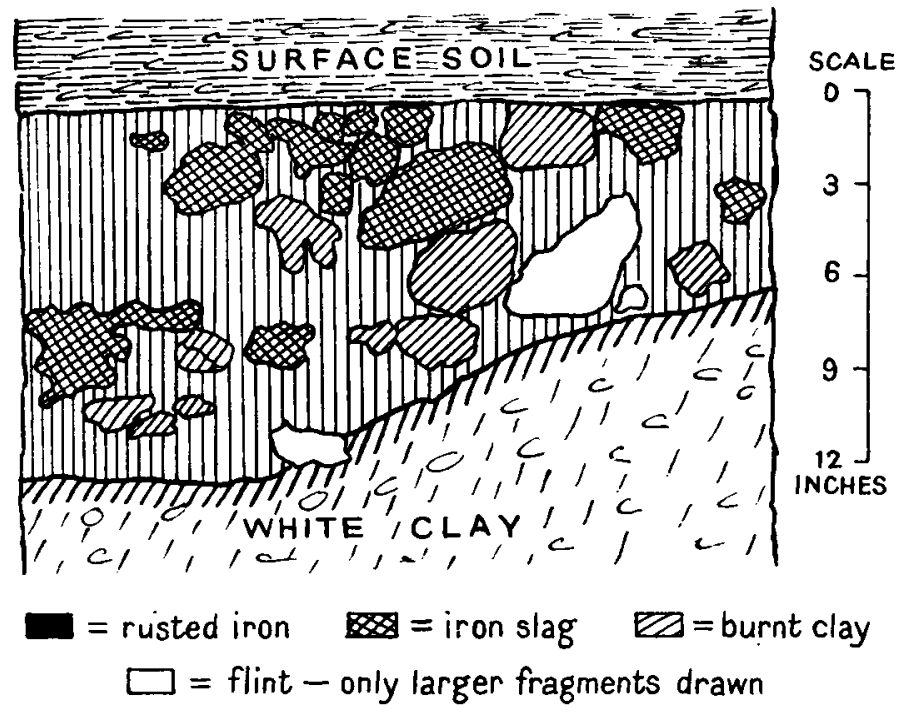

FIg. 5. Section across foundry floor.

had been smelted in a furnace of fair size, not in any small crucible. In one or two lumps of rusted and comparatively pure metalclearly the produce and not the waste of the kilns--well-preserved charcoal running through the mass proved that the process was essentially that known as green-pole smelting whereby boughs are laid in amongst the ore to secure proper carbonization. On the other hand there was no trace of kiln or superstructure, and nothing to explain the use of the long pit nearly $9 \mathrm{ft}$. below the platform level.

On the whole, it would appear that there never was any kiln, properly speaking; that the fuel (presumably charcoal) was laid on the clay floor, the ore, mixed with boughs, piled on it, and the heap so formed plastered with sods and clay, like a charcoalburner's pile, leaving vents at the top for draught. This explanation 
would account for the large lumps of heavily-burnt clay which lay mixed with the ore and slag and did not result from the break-up of the clay surface of the platform. It is tempting to suppose that the pit served in some way as a flue for forced draught, but it had been so disturbed by subsequent gravel-digging that it was impossible with any certainty to ascribe it to any particular use.

Iron-smelting was not, it would seem, the only industry carried on the site. In the clay floor of the platform was found a small shapeless piece of copper (or bronze?) which obviously had leaked down when in a molten state. Moreover, mixed up with the iron slag, were found several lumps of blue-green silicate paste which appear to be enamel coloured with sulphate of copper; so that the characteristic Late Celtic art of enamelling on bronze appears to have been practised here.

Except for one vessel, which was retained by Mr. Collard and is now on exhibition in Canterbury Museum, all the pottery and other objects found during the excavations have been presented to the British Museum. 


\section{INDEX TO PLATES}

The page references refer to the descriptions of the objects illustrated; the main references are placed first.

\begin{tabular}{|c|c|c|c|}
\hline Plat & $I, 1$ & pag & $5, \mathrm{I} 3, \mathrm{I} 5$ \\
\hline ", & $\mathrm{I}, 2$ & " & $5, I I, 12, I 3$ \\
\hline$"$ & II, I & " & $5,11,12,13$ \\
\hline$"$ & II, 2 & ", & $6,9,12,13$ \\
\hline " & III, I & ” & $7, \mathbf{1 0}, \mathbf{1} 3$ \\
\hline , & III, 2 & , & 21,25 \\
\hline " & IV, I & " & $18,21,25$ \\
\hline , & IV $, 2,3$ & ” & 19 \\
\hline$"$ & $V, I, 2,3$ & 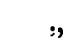 & 20 \\
\hline ” & VI, $\mathbf{I}$ & , & $8,26,7,18,23,25$ \\
\hline ” & VI, 2 & :. & $8,26,4,25$ \\
\hline$"$ & $\mathrm{VI}, 3,4$ & $"$ & $9,24,6,25,26$ \\
\hline , & VII, 5 & , & $9,26,4$ \\
\hline$"$ & VII, 6 & " & $9,26,5$ \\
\hline$"$ & VII, 7 & , & $9,25,5$ \\
\hline$\therefore$ & VII, 8 & ", & $9,25,8,19$ \\
\hline " & VII, 9 & $"$ & $10,25,7,19,26$ \\
\hline " & VII, Io & " & $10,26,5,23,25$ \\
\hline " & VIII, II & ", & I0, $25,7,18,19$ \\
\hline " & VIII, I 2 & ", & $10,26,7$, I9 \\
\hline : & VIII, I3 & , & II, 26, 4, 19 \\
\hline : & VIII, I4 & , & I I, 26, 5, I9 \\
\hline 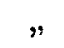 & VIII, I 5 & ", & $11,26,4$ \\
\hline$"$ & VIII, I6 & 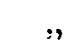 & $1], 26,7$ \\
\hline ” & VIII, I7 & , & $1 \mathrm{I}, 26,5, \mathrm{I} 8, \mathrm{I9}$ \\
\hline " & VIII, I8 & " & $12,26,5$ \\
\hline "y & VIII, I9 & - " & $12,26,7$ \\
\hline " & VIII, 20 & $"$ & 12,27 \\
\hline , & VIII, 21 & ", & $12,26,5,19$ \\
\hline " & IX, 22 & " & $12,24,6,25$ \\
\hline ” & IX, 23 & , & ${ }^{1} 3,24,6,25$ \\
\hline , & IX, 24 & , & $13,25,7$ \\
\hline , & IX, 25 & ", & $13,24,25,6$ \\
\hline$"$ & IX, 26 & , & $13,24,6$ \\
\hline " & IX, 27 & $"$ & ${ }^{1} 3,26,5,18$ \\
\hline ", & IX, 28 & " & I $3,26,5$ \\
\hline
\end{tabular}




\begin{tabular}{|c|c|c|c|}
\hline Pla & IX, 29 & pag & $\mathrm{I} 3,26,5,19$ \\
\hline , & $\mathrm{IX}, 3^{\circ}$ & $"$ & $1_{3}, 26,5$ \\
\hline , & IX, $3^{I}$ & , & $\mathrm{I} 4,25,5, \mathrm{I} 8$ \\
\hline " & IX, 32 & $"$ & $14,27,6,22$ \\
\hline$"$ & IX, 33 & $"$ & $14,26,7$ \\
\hline " & $\mathrm{IX}, 34$ & $"$ & $15,26,5,18,24$ \\
\hline$"$ & IX, 35 & $"$ & $15,26,7$ \\
\hline , & $X, 1,2,3$ & " & I 6 \\
\hline " & $X, 4$ & $\because$ & 2.5 \\
\hline ” & $X, 5$ & $"$ & $2 I$ \\
\hline , & $\mathrm{X}, 6$ & 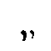 & 22,8 \\
\hline ” & $X, 7$ & , & $\mathrm{I} 6,2 \mathrm{I}$ \\
\hline$"$ & $X I, I$ & , & $16,21,22,25$ \\
\hline " & $X I, 2,3$ & " & 22 \\
\hline , & XI, 4 & ", & 20 \\
\hline ” & $\mathrm{XI}, 5$ & $"$ & $20,24,27$ \\
\hline ” & $X I, 6$ & 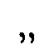 & 20 \\
\hline , & $\mathrm{XI}, 7$ & $"$ & I 6,20 \\
\hline$"$ & $\mathrm{XI}, 8$ & $"$ & 20 \\
\hline$"$ & XI, 9 & , & $2 \cdot 2$ \\
\hline , & XII, I & $"$ & $40,45,5,25$ \\
\hline , & XII, 2 & $"$ & $40,45,7,18,25,43$ \\
\hline , & XII, 3 & , & $41,45,6,18,24,25,27$ \\
\hline$"$ & XII, 4 & $"$ & $4 I, 45,4,18,26,43,44$ \\
\hline ” & XII, 5 & $"$ & $42,45,8,18,25,43$ \\
\hline , & XII, 6 & $"$ & $42,45,8,25$ \\
\hline " & XIII, 7 & $\therefore$ & $18,43,45,25,40,42,44$ \\
\hline$"$ & XIII, 8 & $"$ & $\mathrm{I} 8,43,45,4 \mathrm{I}$ \\
\hline , & XIII, 9 & $"$ & I $9,43,45,44$ \\
\hline , & $X I V, 10,11$ & , & $4.3,45,20,4 \mathrm{I}, 44$ \\
\hline$"$ & $\mathrm{XIV}, \mathrm{I} 2$ & $"$ & $44,45,20,43$ \\
\hline :, & XIV, I3 & $"$ & $44,45,22,41,42,43$ \\
\hline ", & XIV, 17 & $n$ & 45 \\
\hline$"$ & $\mathrm{XV}, 14,15$ & $"$ & $44,45,20,24$ \\
\hline$"$ & $X V, 16$ & $"$ & 44,45 \\
\hline$"$ & XVI & , & 4,2 \\
\hline
\end{tabular}




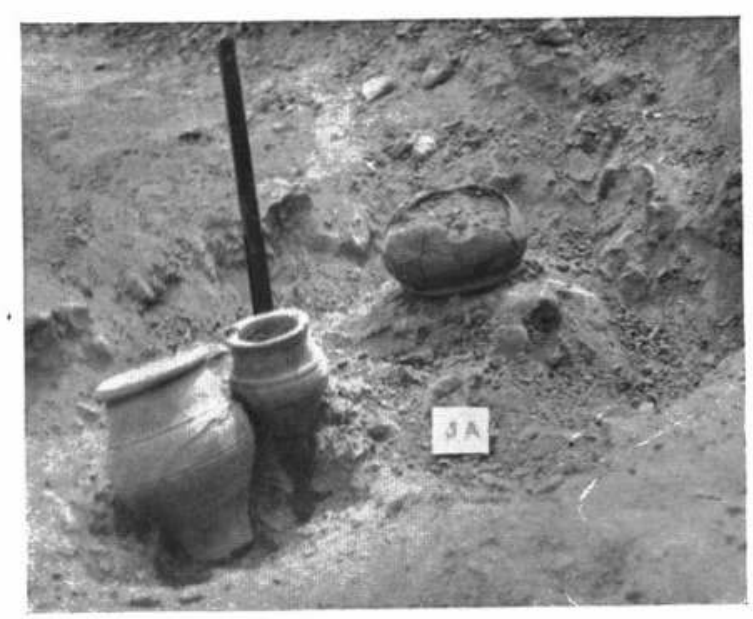

Fig. I. Swarling: Grave Group 5

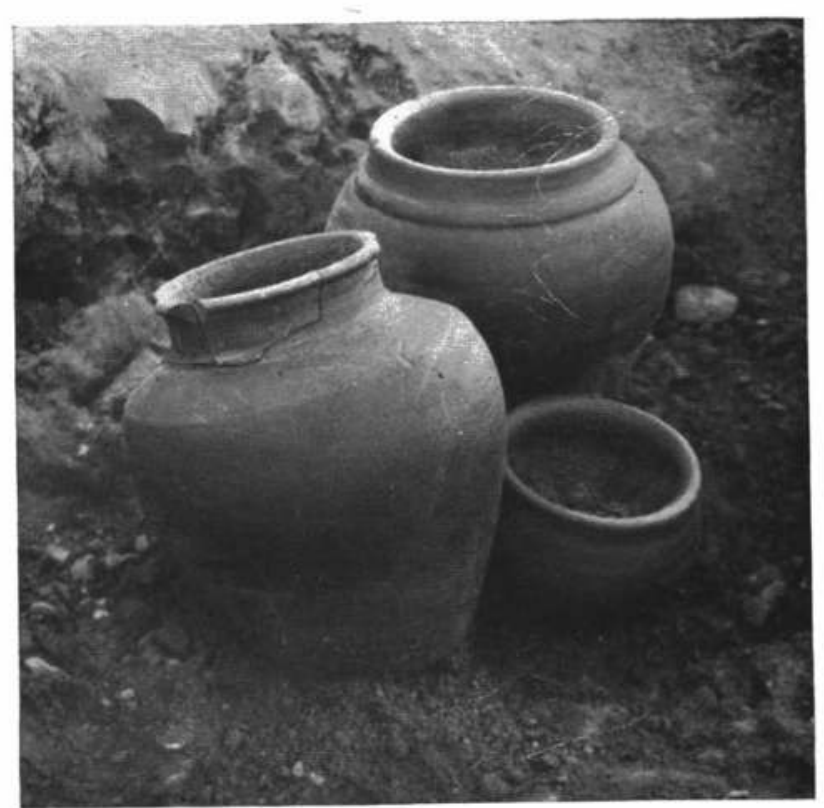

Fig. 2. Swarling: Grave Group 8 


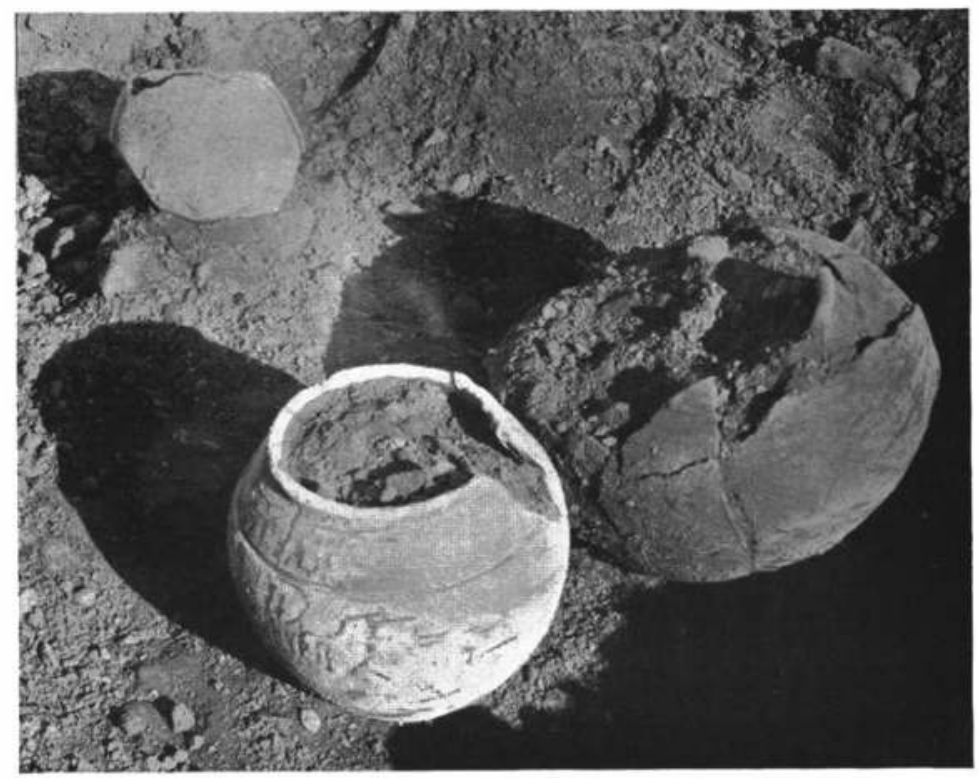

Fig. I. Swarling: Grave Group 9

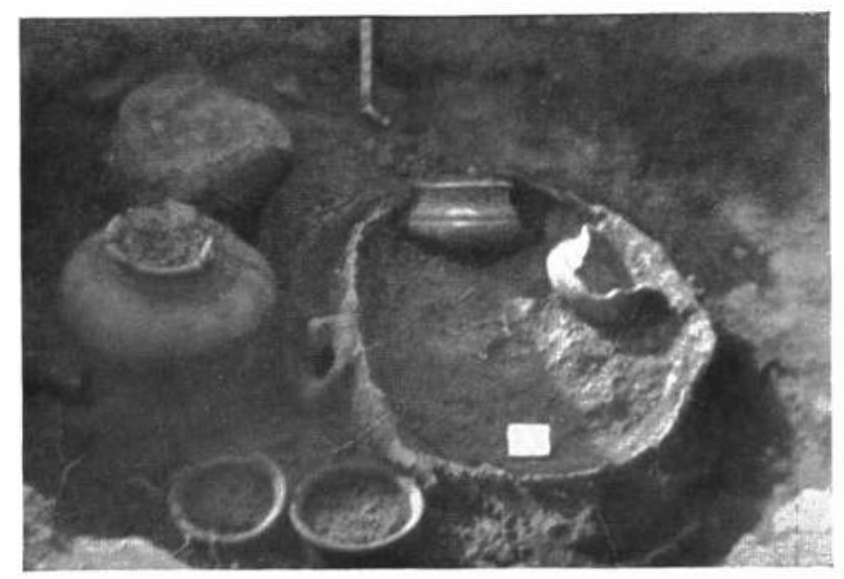

Fig. 2. Swarling: Grave Group I3 
Plate III

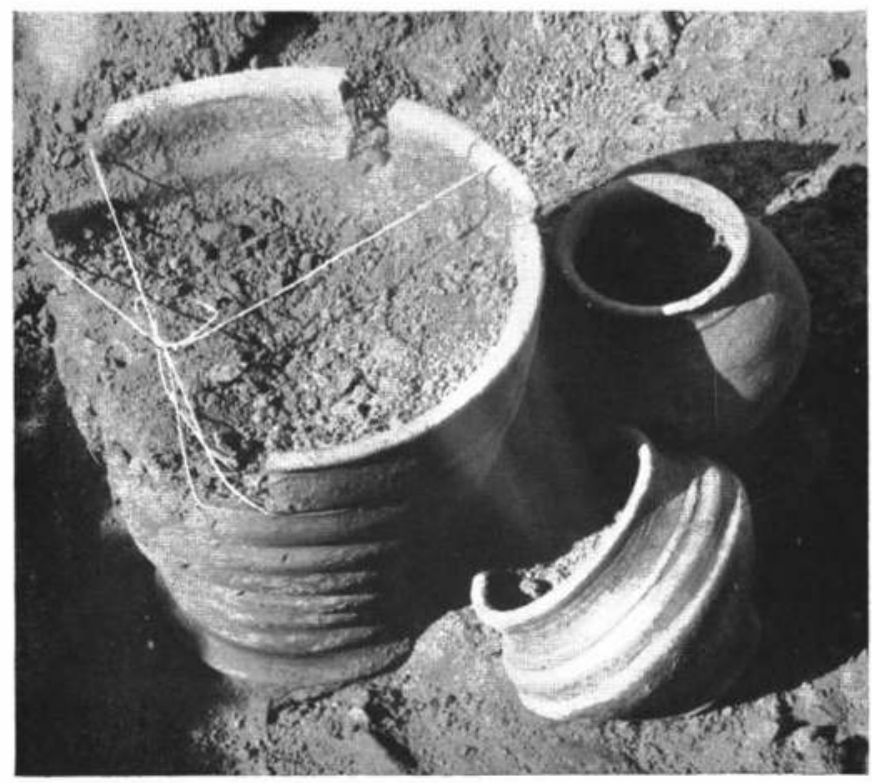

Fig. I. Swarling: Grave Group 18

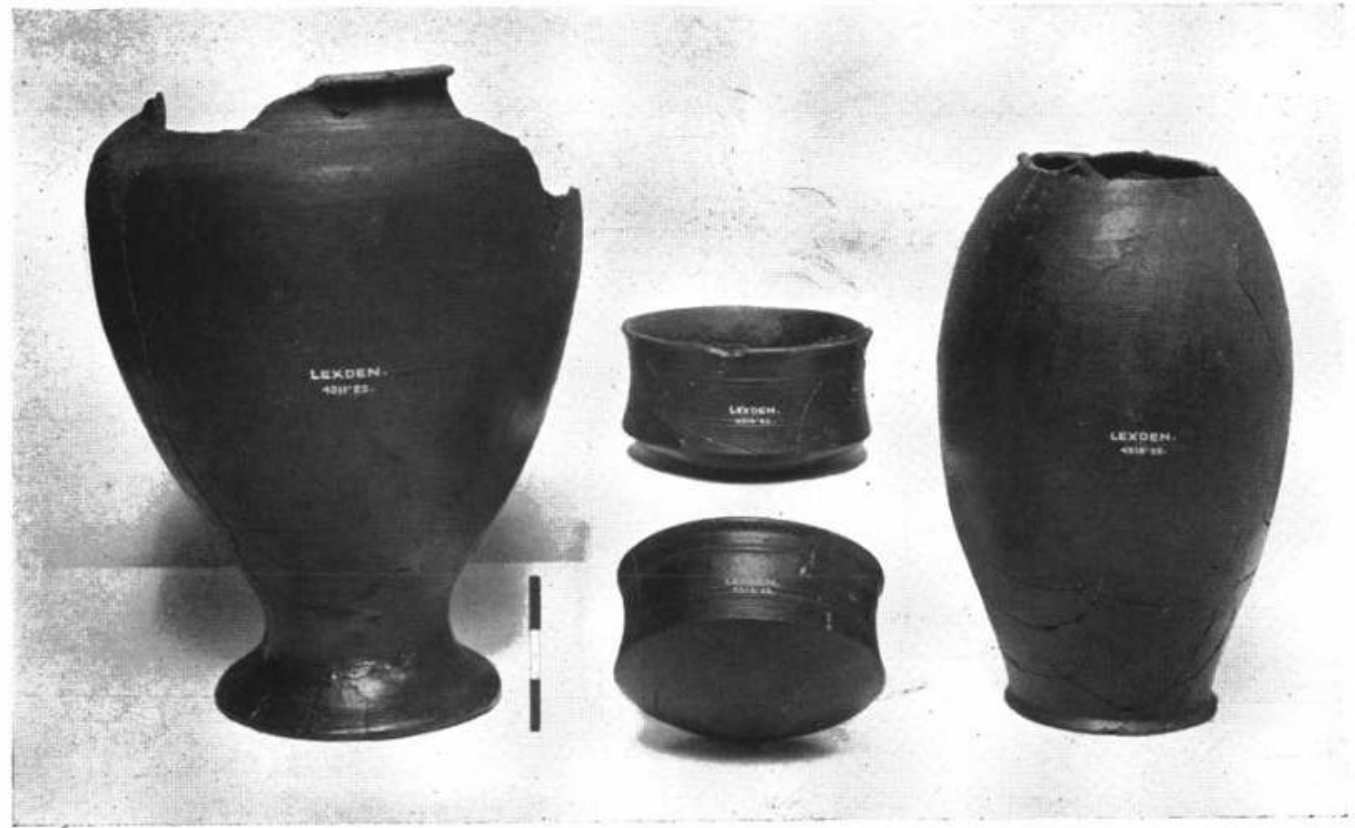

Fig. 2. Grave Group from Lexden near Colchester

Publisbed by the Sociely of Antiquaries of London, 1925 


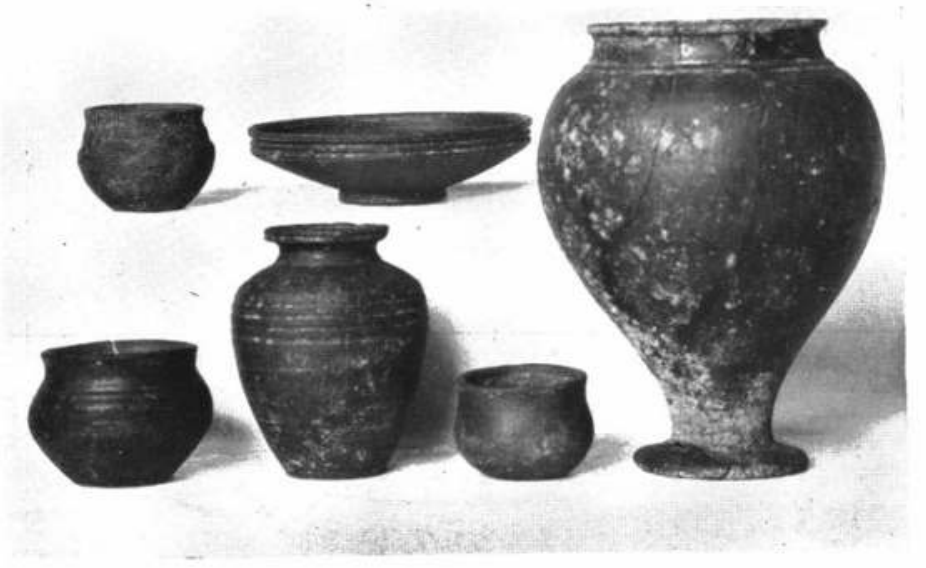

Fig. I. Burial Group from Deal

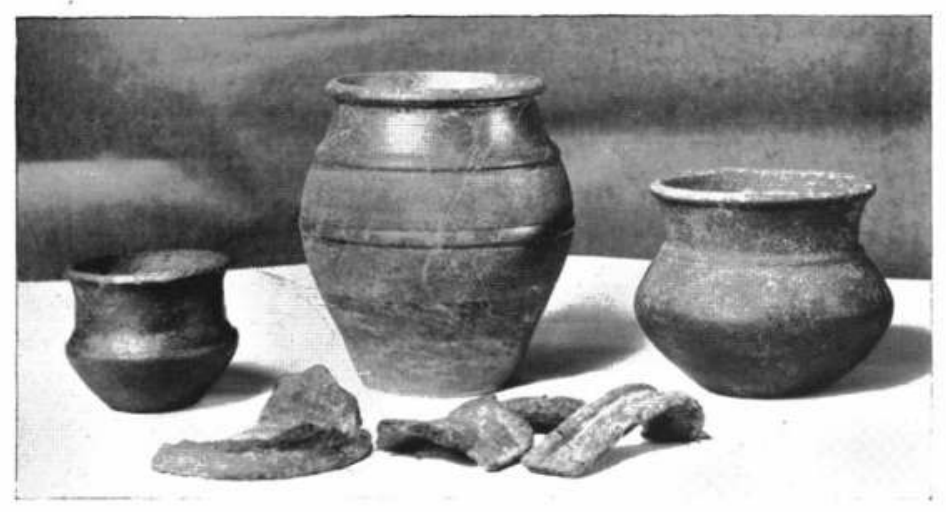

Fig. 2. Burial Group from Deal

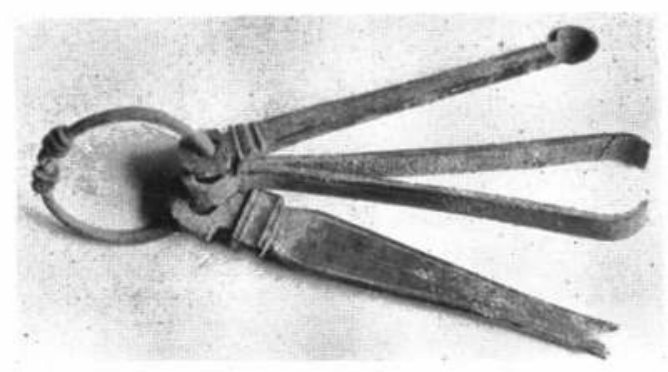

Fig. 3. Toilet set from Deal

Published by the Society of Antiquaries of London, 1925 


\section{Plate V}

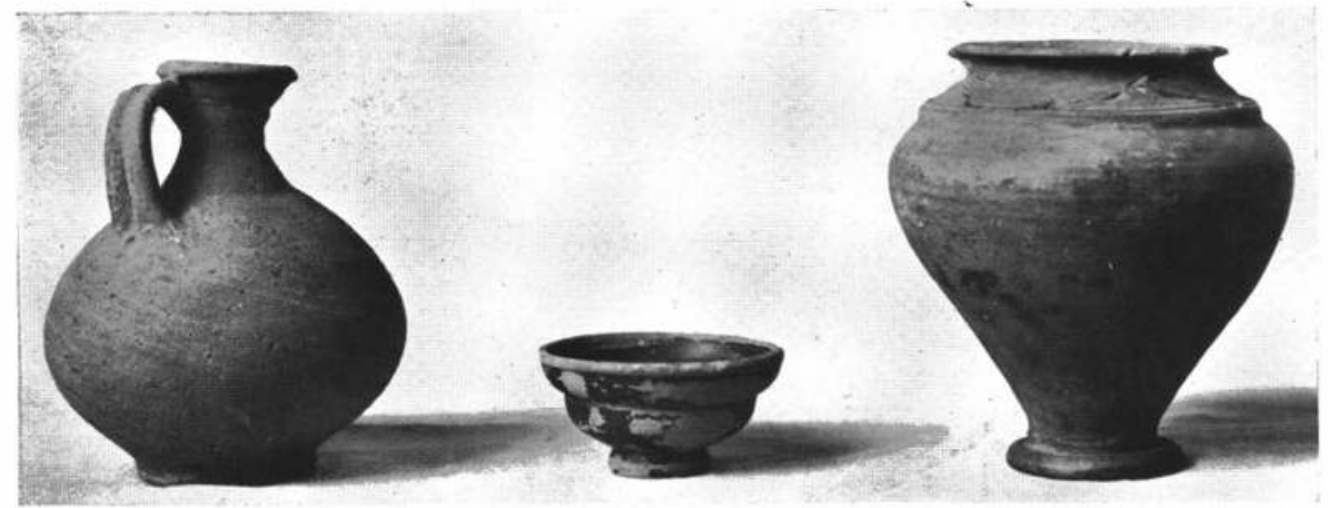

Fig. I. Burial Group from Folkestone

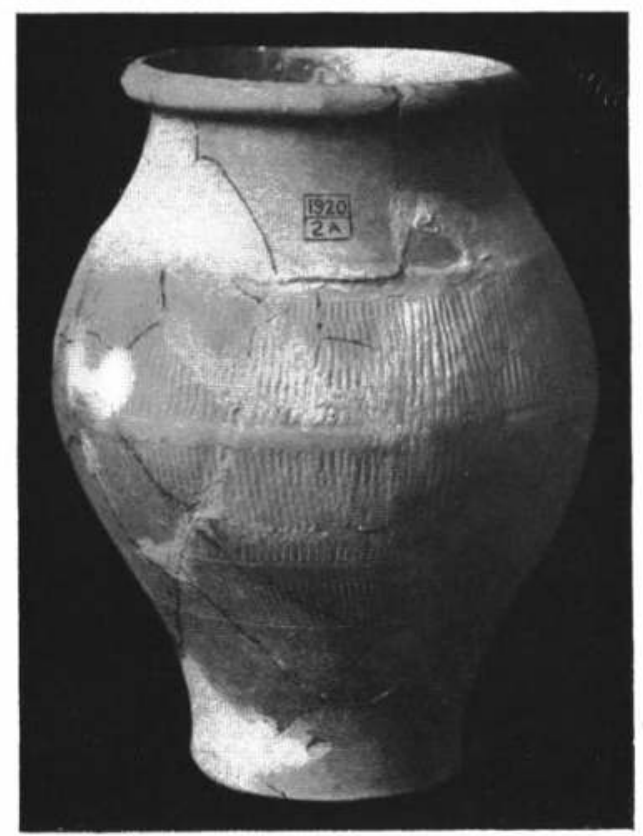

Fig. 2. Urn from Folkestone

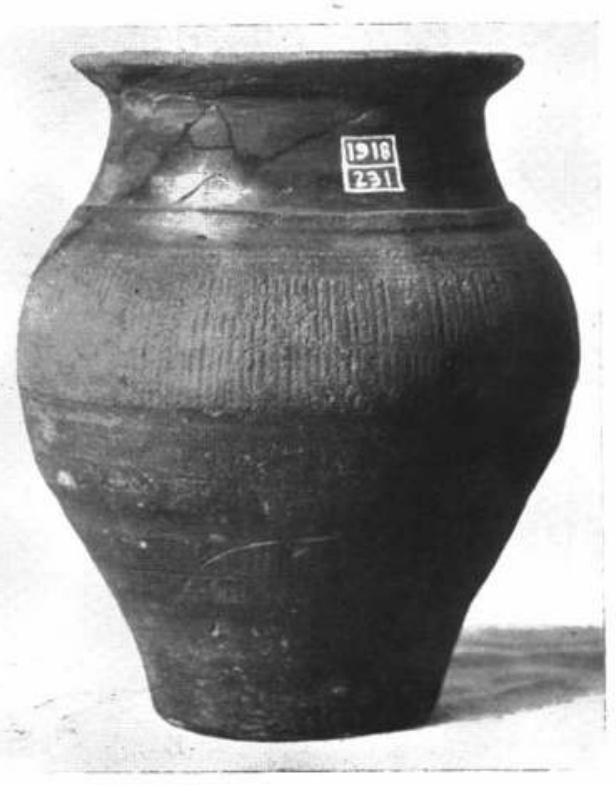

Fig. 3. Urn from Folkestone

Published by the Society of Antiquaries of London, 1925 

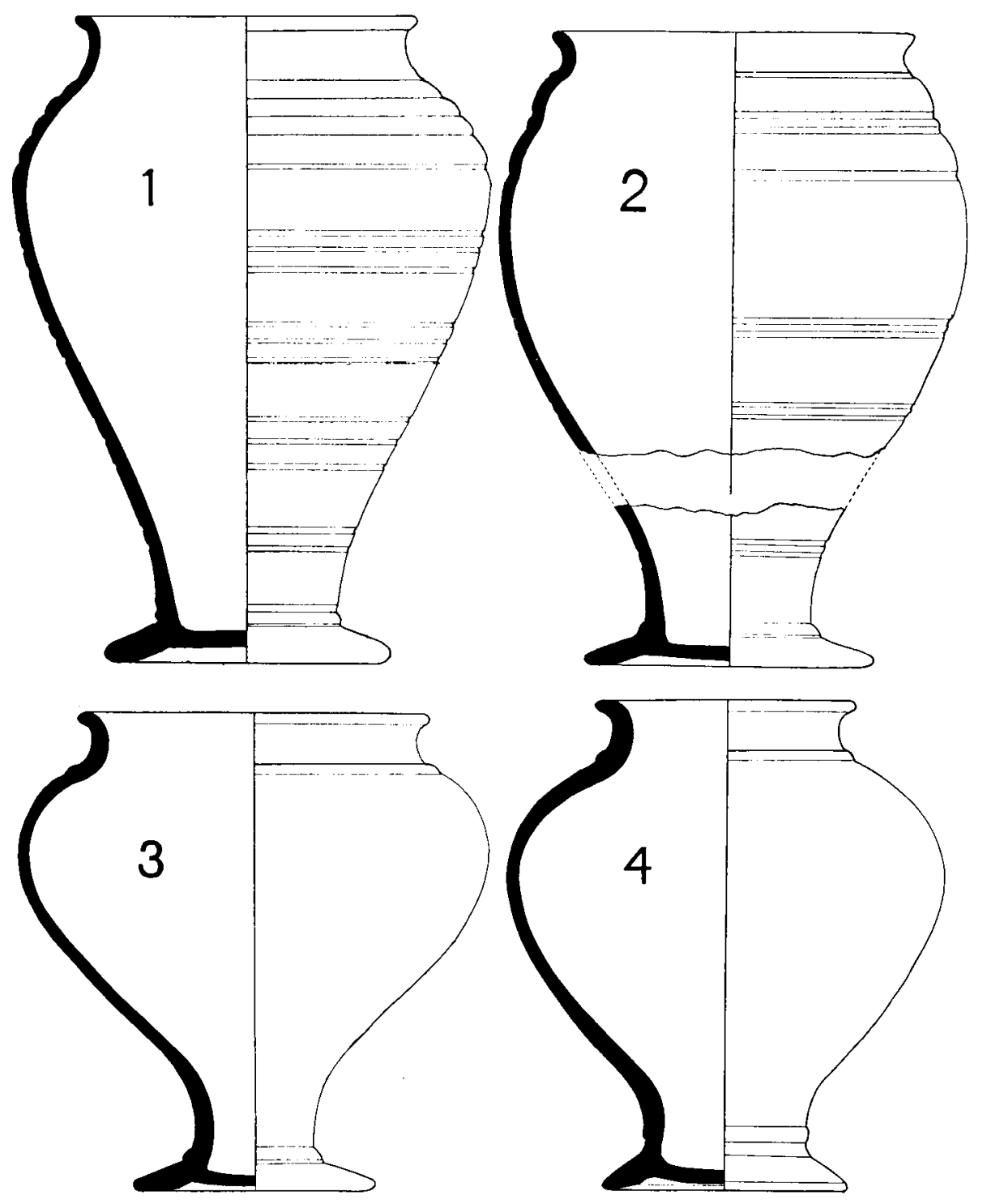

Swarling pottery: nos. I-4 ( $\left.\frac{1}{4}\right)$

Published by the Society of Antiquaries of London, 1925 

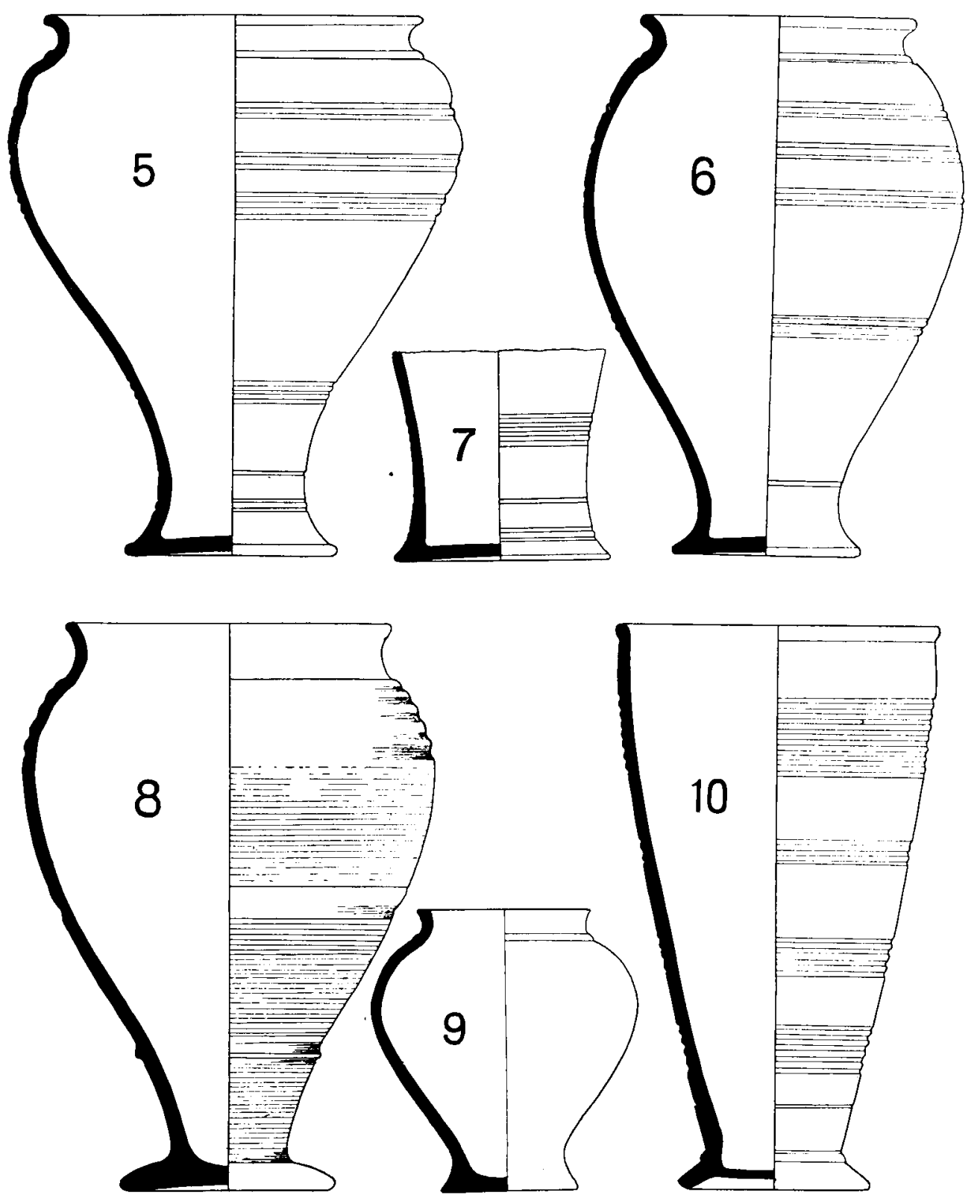

Swarling pottery: nos. 5-1० $\left(\frac{1}{4}\right)$

Published by the Society of Antiquaries of London, 1925 
Plate Vili

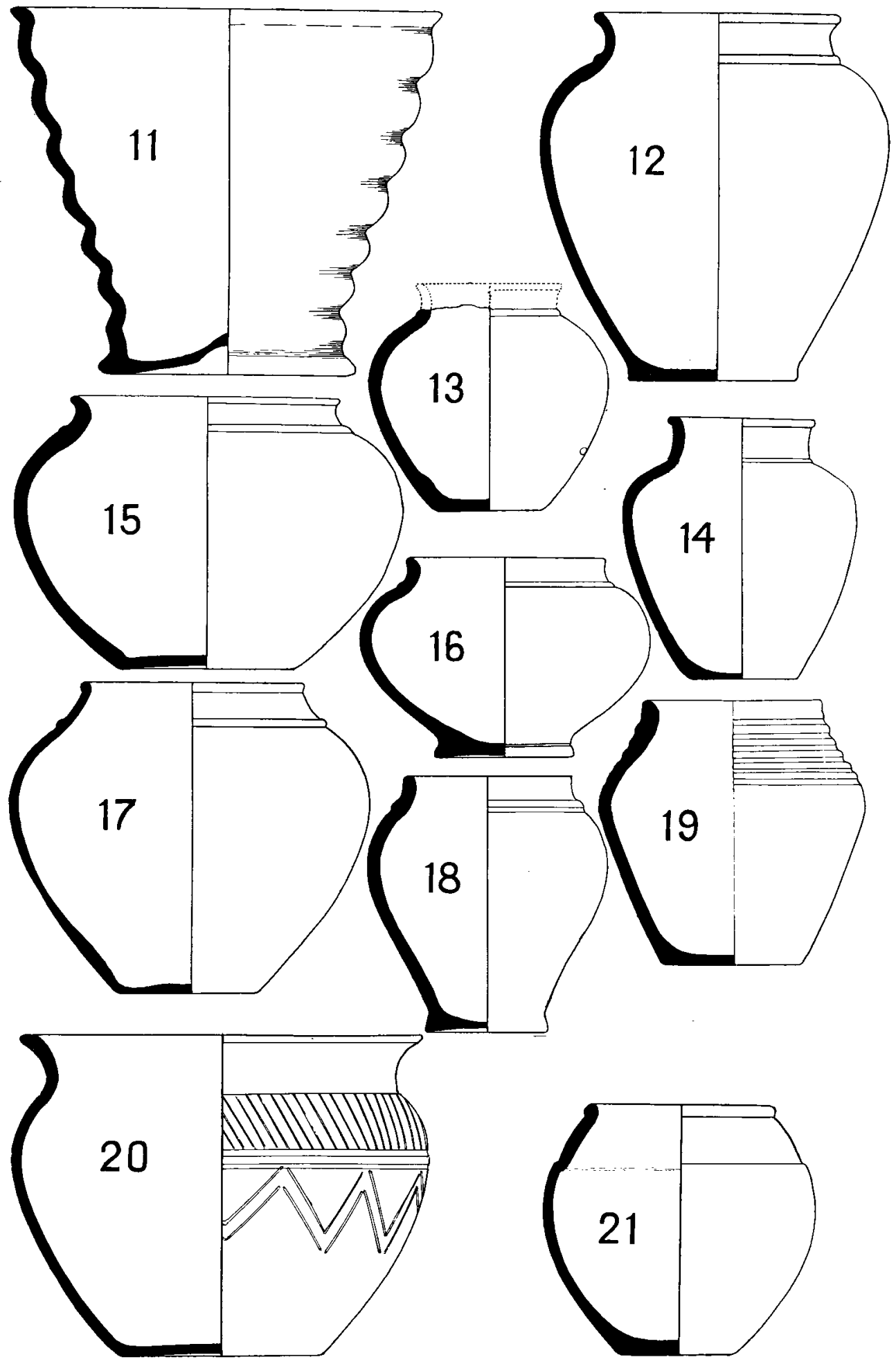

Swarling pottery: nos I I-2I ( $\left.\frac{1}{4}\right)$

Published by the Society of Antiquaries of London, 1925 

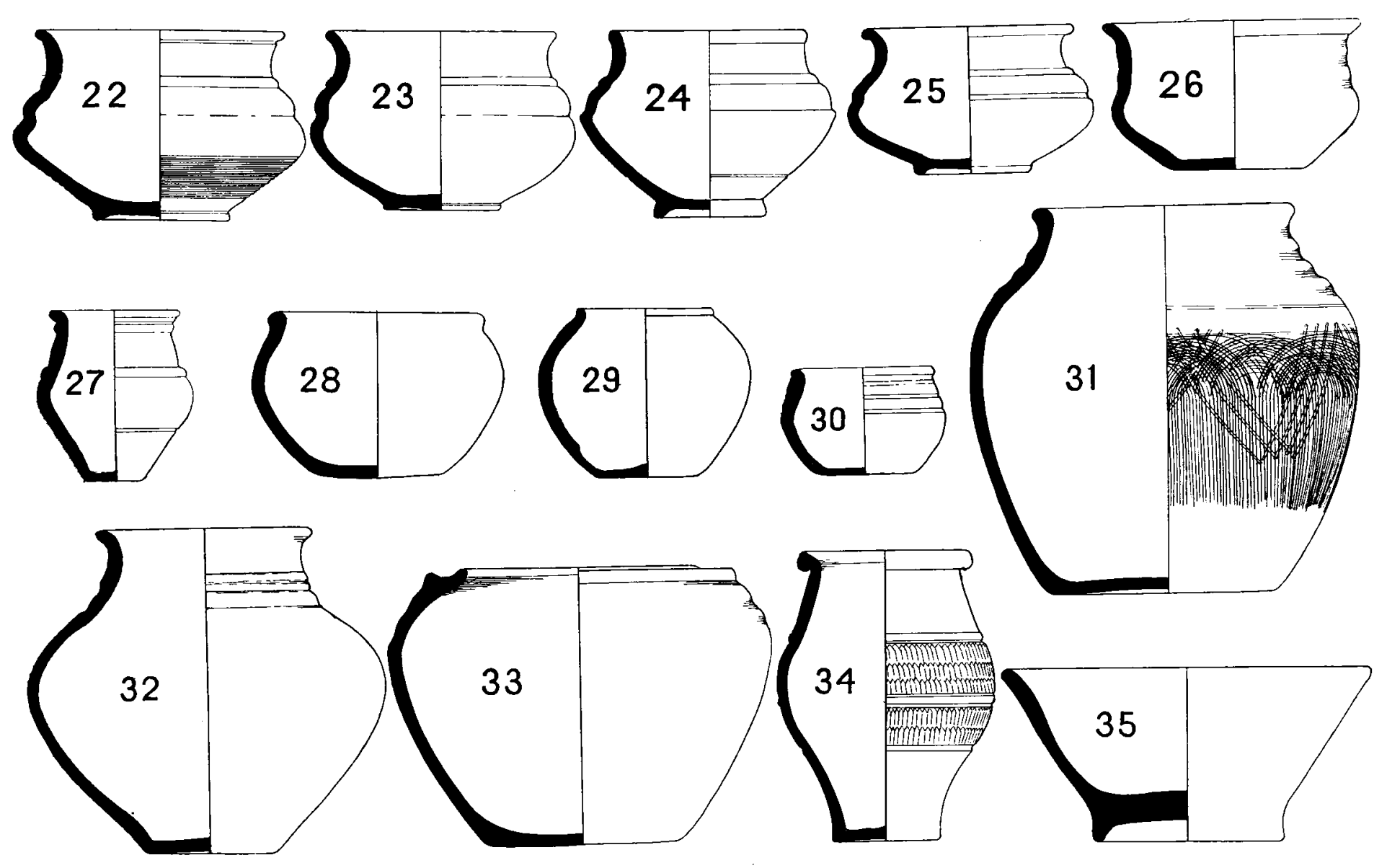

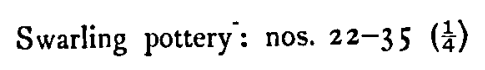

Published by the Society of Antiquaries of London, 1925 
Plate X
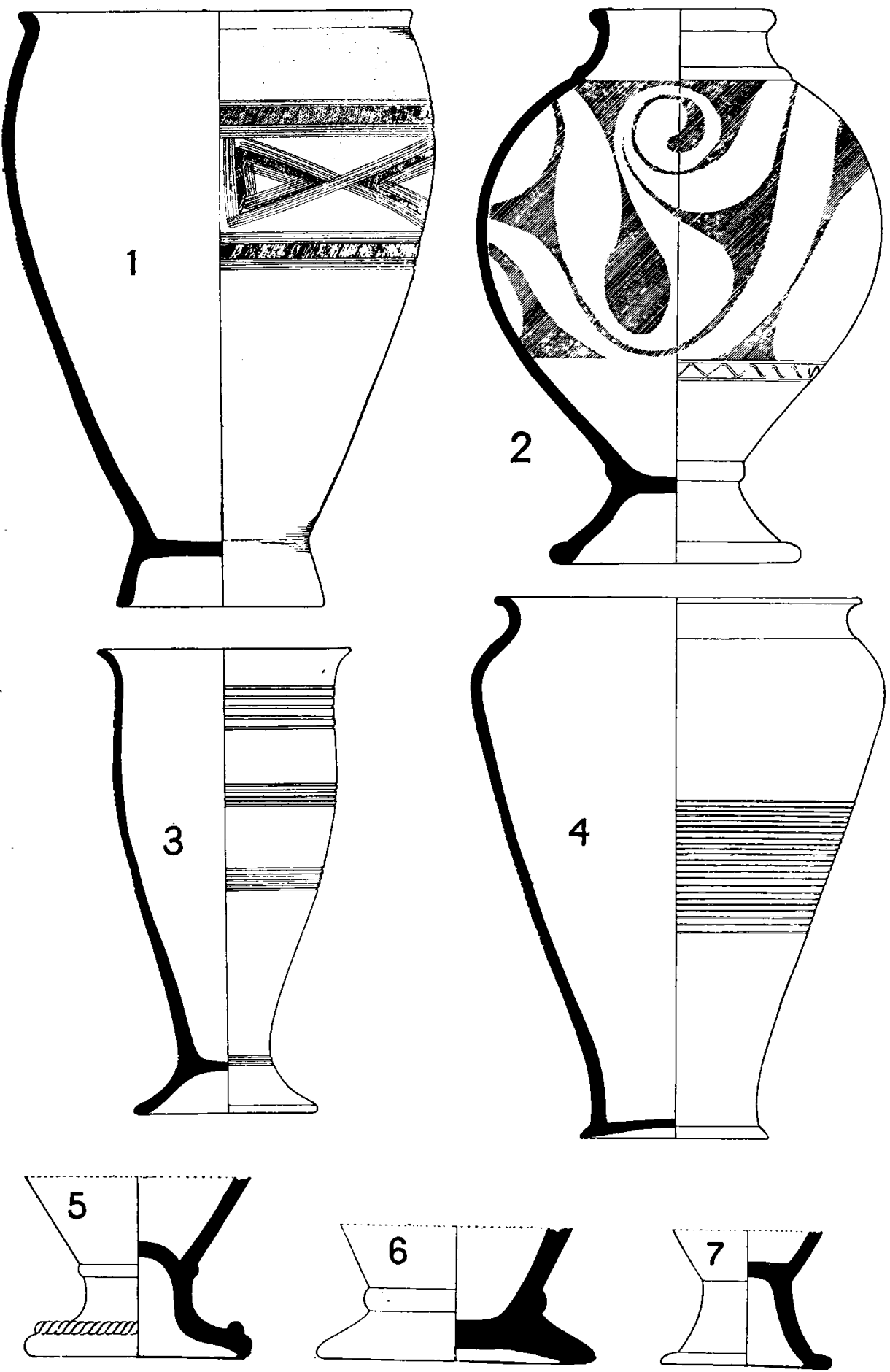

Pottery: 1-4, Marne and Aisne, Brit. Mus.; 5, 7, Colchester 6, Shoeburyness ( $\left.\frac{1}{4}\right)$ 


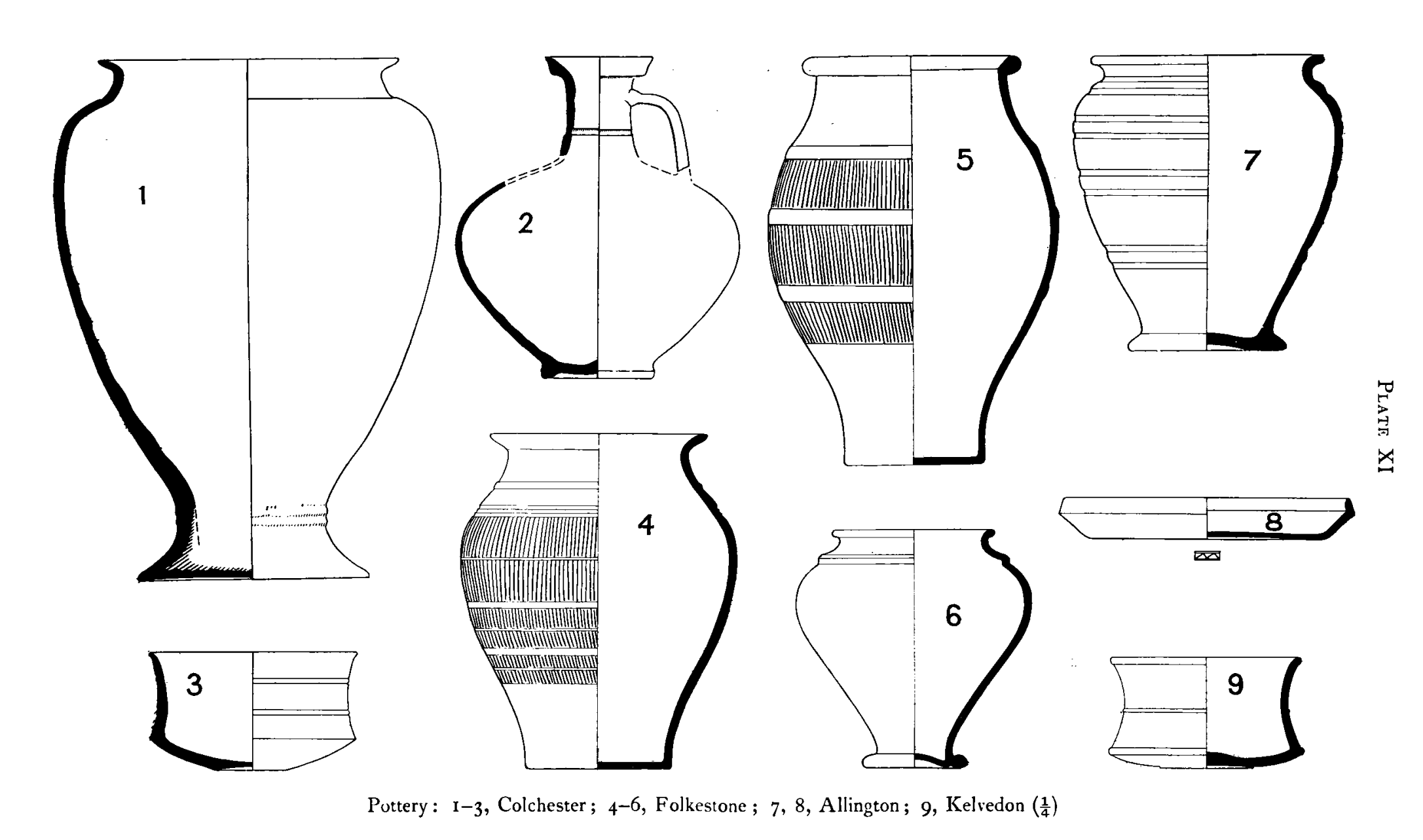




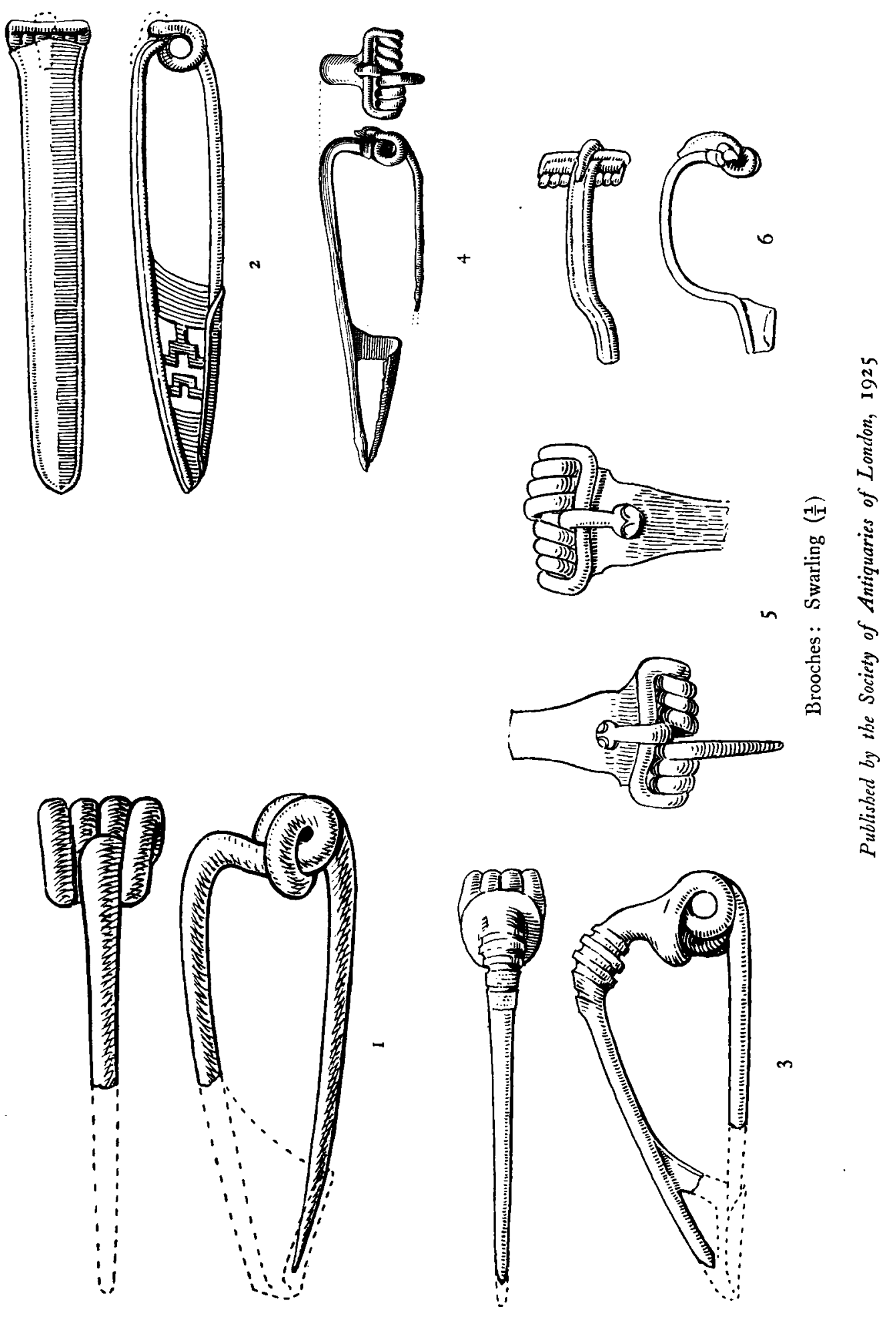




\section{Piate XIII}
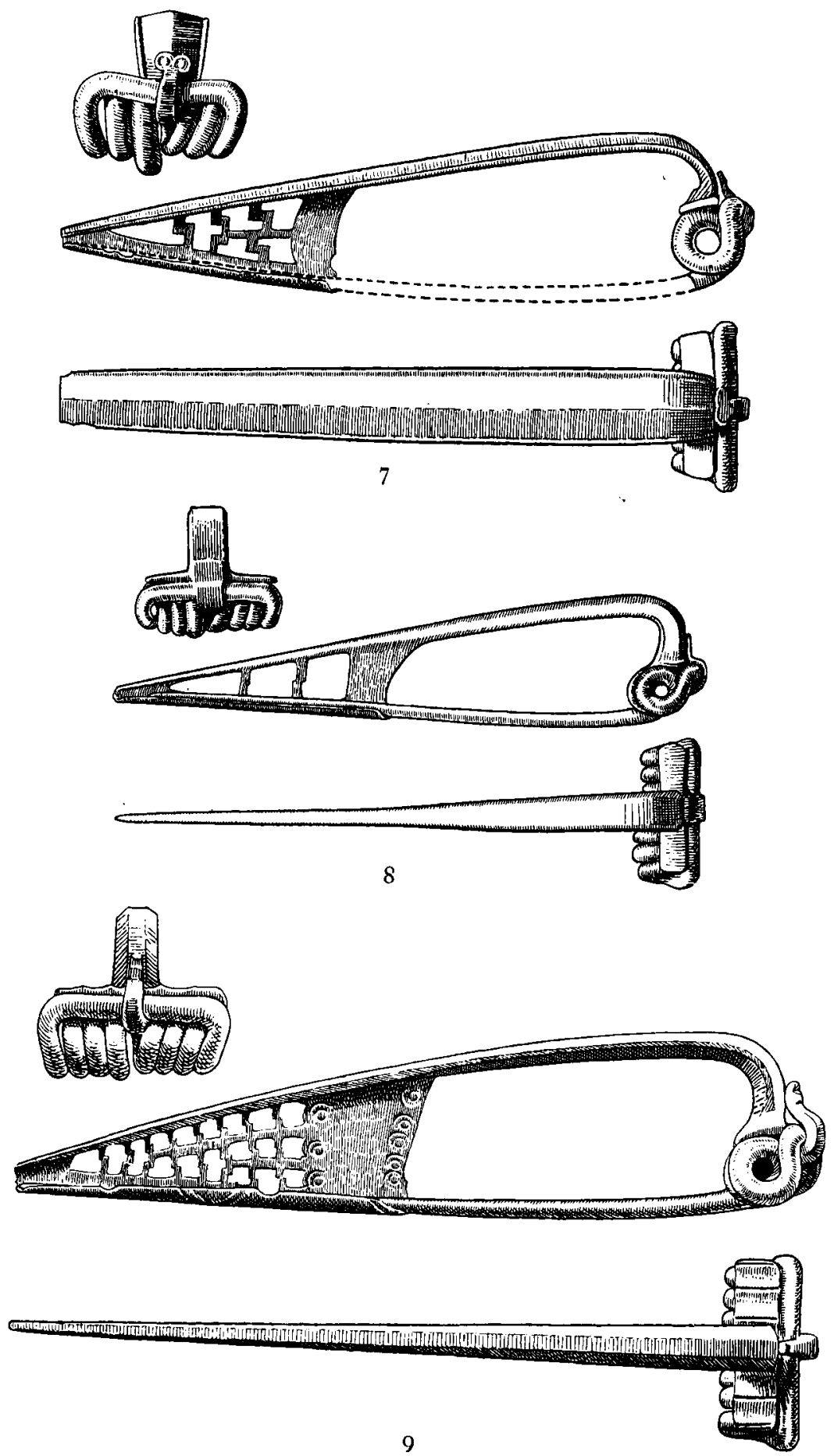

Brooches : Deal $\left(\begin{array}{l}1 \\ 1\end{array}\right)$

Published by the Society of Antiquaries of London, 1925 

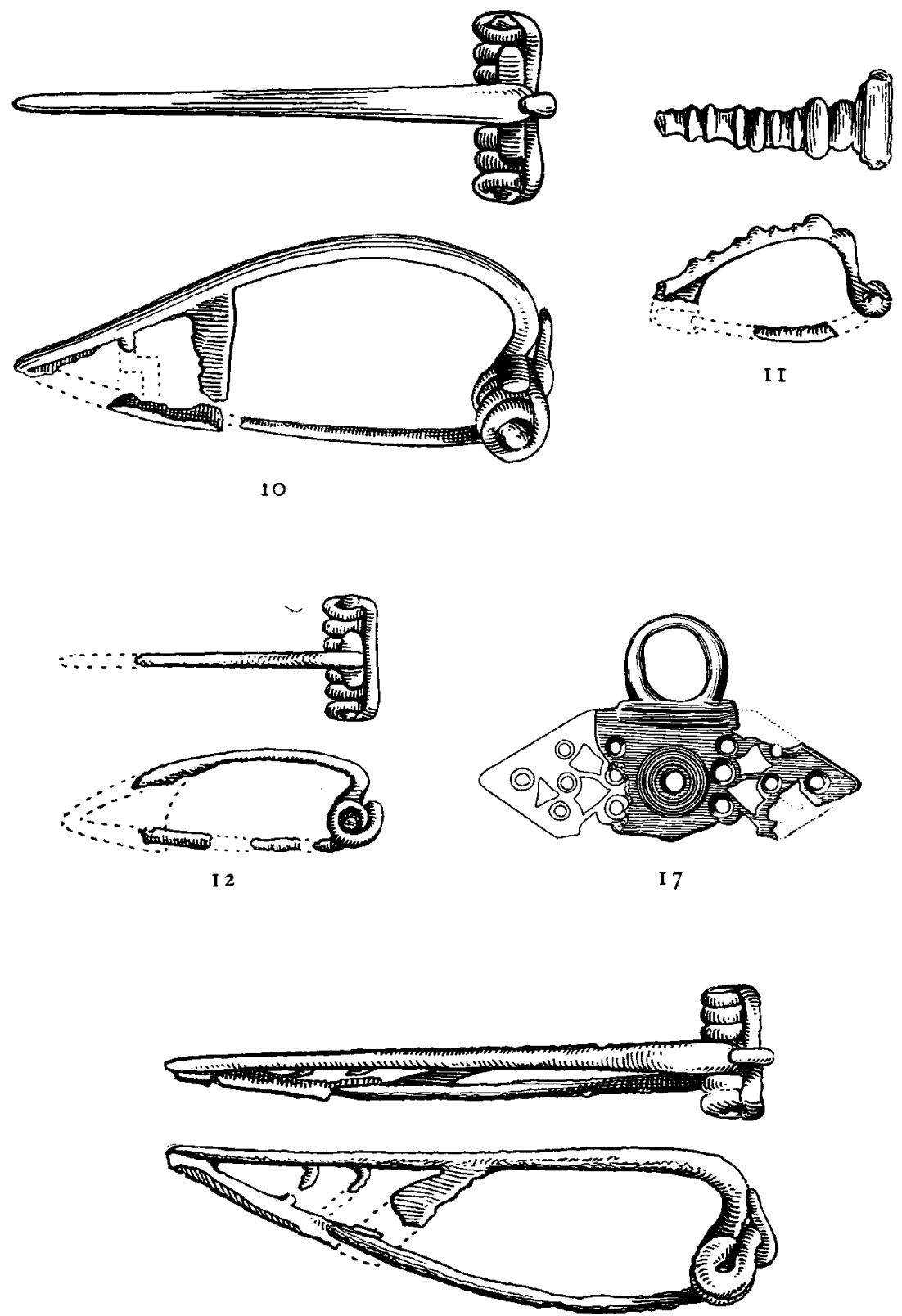

I3

Brooches: 10-I 2, Folkestone; I 3, Kelvedon I7, Bucket scutcheon, Swarling ( $\left.\frac{1}{1}\right)$

Published by the Society of Antiquaries of London, 1925 

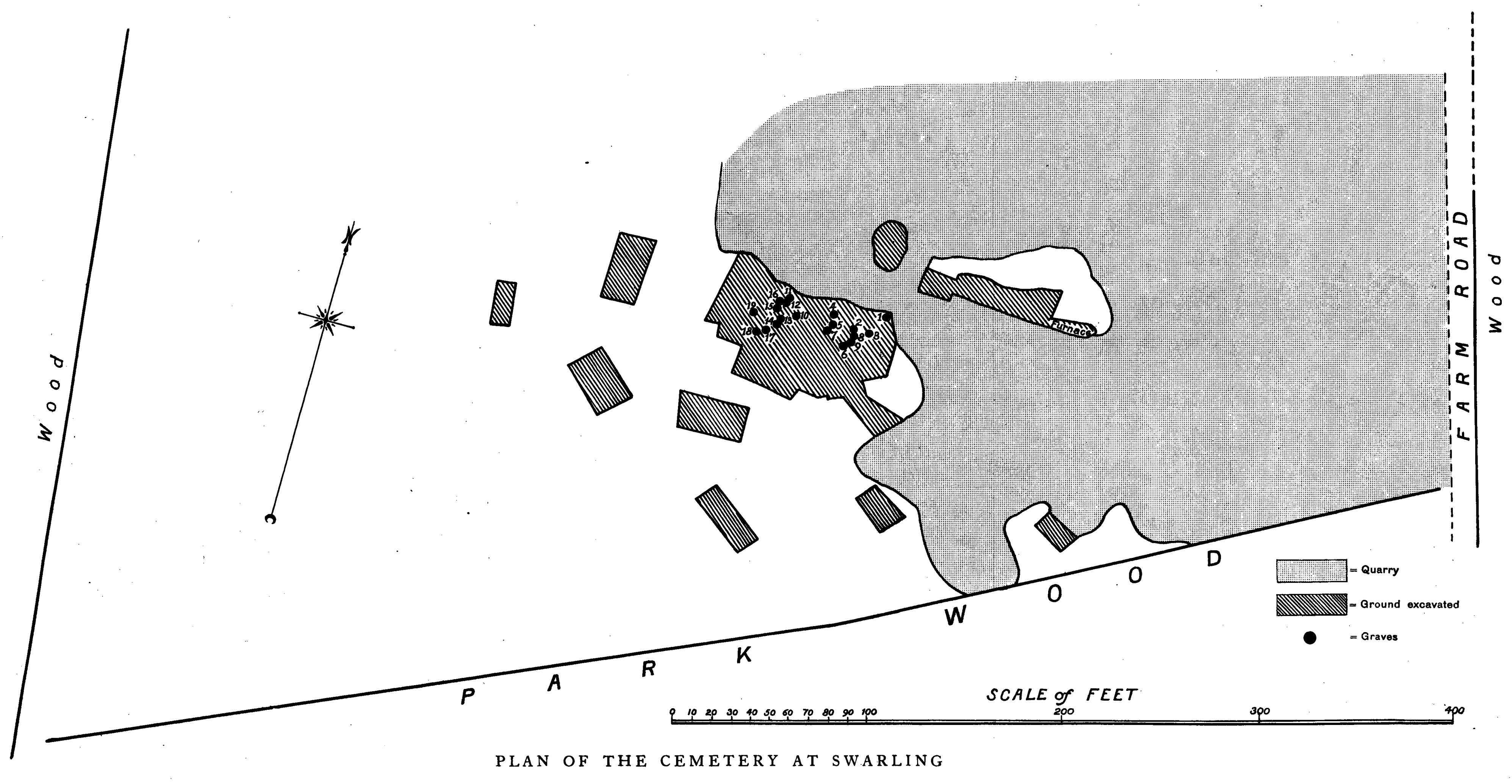

PLAN OF THE CEMETERY AT SWARLING

Publisbed by the Society of Antiquaries of. London, 1925 


\section{Plate XV}

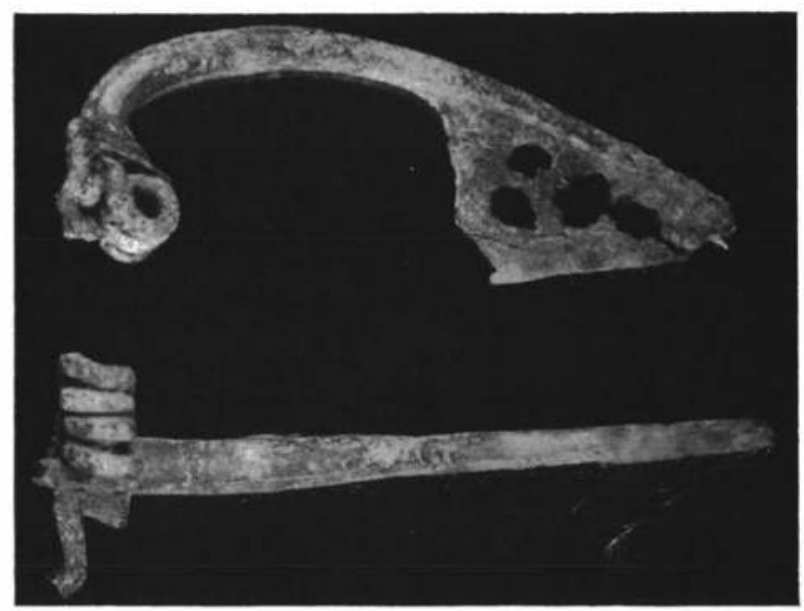

14

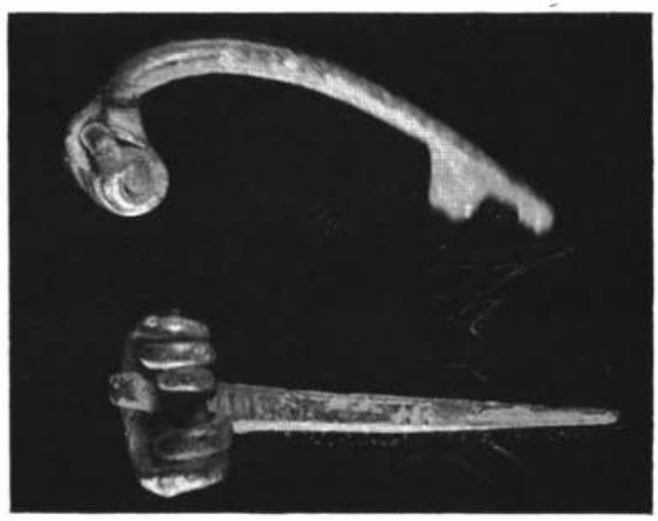

15

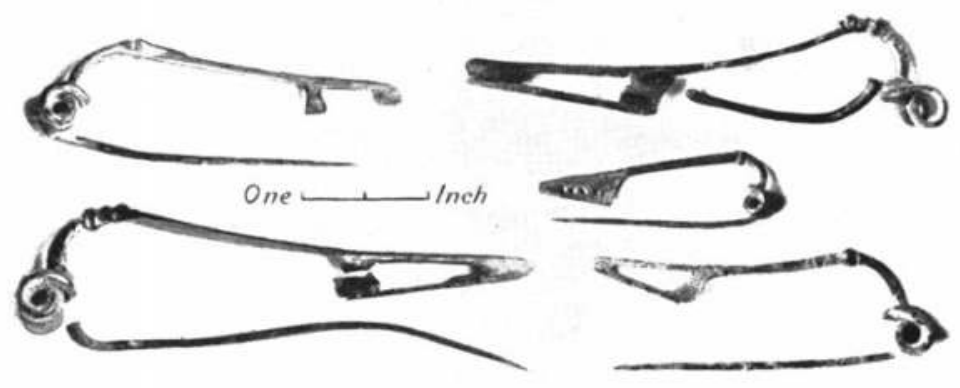

I 6

Brooches: 14,15 , Allington $\left(\frac{1}{1}\right) ; 16$, Deal $\left(\frac{1}{2}\right)$

Publisbed by the Society of Antiquaries of London, 1925 